\title{
33. SEDIMENTARY SEQUENCES INFLUENCED BY SUBMARINE FAN DEPOSITION: ARGO ABYSSAL PLAIN, NORTHWESTERN AUSTRALIA ${ }^{1}$
}

\author{
Cedric M. Griffiths, ${ }^{2}$ David C. Kopaska-Merkel, ${ }^{3}$ and M. Schott ${ }^{4}$
}

\begin{abstract}
Transition probabilities from both core descriptions and wireline-log data from the Miocene section of Ocean Drilling Program Leg 123 Site 765 are examined. The data cover $270 \mathrm{~m}$ of section dominated by carbonate turbidites with varying silica content. Although the significant transitions do not echo the "classic" Bouma sequence, statistically significant cycles and pair-oscillation appear to be common when substitution of facies is taken into account. The sequence is zoned using both visual core-description and minimum-variance zonation of the wireline data. Significant transition probabilities are calculated, and syntaxes developed for both data sets. Syntactic pattern recognition is conducted using the wireline-log data to map the completeness of the section. These analyses support the hypothesis that the low average sedimentation rate during the Miocene $(2 \mathrm{~cm} / \mathrm{k} . \mathrm{y}$.) is more likely a result of sediment starvation or bypassing than active erosion, with its concomitant disturbance of regular and significant cycles.
\end{abstract}

\section{INTRODUCTION}

In this chapter, we discuss the identification of Miocene lithostratigraphic sequences from both sediment description and wireline-log data from Leg 123 Hole $765 \mathrm{C}$. This hole was drilled in the Argo Abyssal Plain, $60 \mathrm{~km}$ north of Swan Canyon on the northern edge of the Exmouth Plateau, northwestern Australia (Fig. 1). The Argo Abyssal Plain is bounded to the south by the Exmouth Plateau and underlain by Cretaceous (to possibly Jurassic) oceanic crust. The post-mid-Jurassic Northwest Australian Shelf has been described as a sediment-starved passive margin by von Rad and Exon (1982). The water depth at the site is $5.7 \mathrm{~km}$, and the Miocene section consists of $300 \mathrm{~m}$ of calcareous turbidites and debris flows from $\sim 180 \mathrm{~m}$ below sea floor (mbsf) to $\sim 480$ mbsf. Hemipelagic clays are a minor constituent.

A consideration of the shelf-edge topography shows that probably throughout the Miocene, Site 765 lay in the path of sediment pouring down Swan Canyon and other canyons in the Exmouth Plateau and Rowley Terrace. Indeed, the site is at the focus of a natural amphitheater of steep escarpments (with slopes of $4^{\circ}-8^{\circ}$ today; by comparison, the steepest part of the Indus fan has a slope of $0.1^{\circ}$ (Kolla and Coumes, 1985), and the Mississippi Fan a slope of $2^{\circ}$ (Bouma et al., 1985)). Despite the existence of this potential high-energy environment near Site 765, the average (nondecompacted) sedimentation rate during the early Miocene was only $\sim 2$ $\mathrm{cm} / \mathrm{k}$.y., which increased to $\sim 3.5 \mathrm{~cm} / \mathrm{k} . \mathrm{y}$. during the late Miocene. This should be compared with what Shanmugam et al. (1985) considered low pelagic rates $(3-30 \mathrm{~cm} / \mathrm{k} . \mathrm{y}$.) and high turbidite rates $(1200 \mathrm{~cm} / \mathrm{k} . \mathrm{y}$.) for recent submarine fans. The Miocene section at Site 765 thus represents anomalously slow deposition for a turbidite system.

Possible reasons for the low sediment-accumulation rate of the Miocene turbidite system at Site 765 include (1) most turbidites bypass the site, (2) low sediment supplied to the Exmouth Plateau and Rowley Terrace throughout the Miocene, or (3) erosion al-

\footnotetext{
${ }^{1}$ Gradstein, F. M., Ludden, J. N., et al., 1992. Proc. ODP. Sci. Results, 123: College Station, TX (Ocean Drilling Program).

2 University of Trondheim, Division of Petroleum Engineering and Applied Geophysics, S. P. Andersens v, 15a, N-7034 Trondheim-NTH, Norway.

3 Energy and Coastal Geology Division, Geological Survey of Alabama, 420 Hackberry Ln., P.O. Box O, Tuscaloosa AL 35486-9780, U.S.A.

${ }^{4}$ Schleissheimer Str. 66, 8000 München 40, F.R.G.
}

most balanced sedimentation. Sediment might have been supplied to the slope by (1) infrequent mass-wasting events, (2) more-orless continuous supply of sediment, or (3) a combination of the two. If infrequent mass-wasting events provided much of the sediment to Site 765 during the Miocene, then one would expect to find thick sedimentation units that are few in number. Conversely, if low-amplitude events predominated, then one would expect to find abundant, relatively thin sedimentation units. All of the strata described here consist of abundant, relatively thin sedimentation units.

Were low sediment supply the cause of this low rate of sediment accumulation at Site 765 during the Miocene, one might expect more complete "Bouma" sequences to be developed in turbidites, possibly dominated by pelagic components (Fig. 2). The explanation is that two classes of phenomena may contribute to the preservation of incomplete turbidite sequences: (1) syndepositional factors and (2) post-depositional factors. Syndepositional factors include flow instability, depositional mechanisms, and flow composition. Post-depositional factors include bioturbation and erosion. Clearly, if two sedimentary sequences dominated by turbidites experienced similar syndepositional conditions, then it was the post-depositional factors that exerted the ultimate control on turbidite-sequence completeness. In such a case, sequences affected by erosive processes must be less complete than sequences unaffected by erosion.

If erosion were the explanation for the low sediment-accumulation rate, then one would expect irregularity of sequence, with fewer complete cycles and common erosion surfaces; pelagic components would be underrepresented. The term "erosion" applies to a multitude of processes that act on a variety of scales. However, all erosive processes have the potential to truncate turbidite sequences. Therefore, we recognize that erosion is more likely to lead to less-complete turbidite sequences than is low sediment supply, and we make no attempt to distinguish between amounts and frequencies of turbidite-sequence truncation that may result from differing erosive processes.

If most sediment bypassed the site, then relatively thick pelagic intervals may be interspersed with overbank flow deposits. Here, identification of the most probable explanation for the low sediment-accumulation rate at Site 765 during the Miocene is facilitated by semiquantitative sequence analysis.

Although the mathematical tools for sequence analysis have been available for some time, their application to real problems 


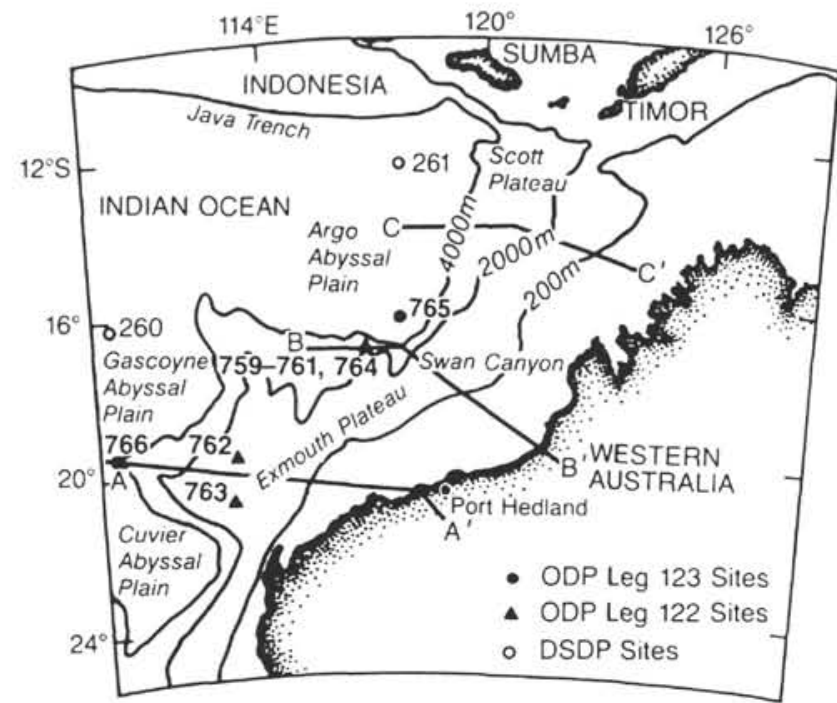

Figure 1. Geographic location of Sites 765 and 766 in the northeastern Indian Ocean.

\section{BOUMA SEQUENCE}

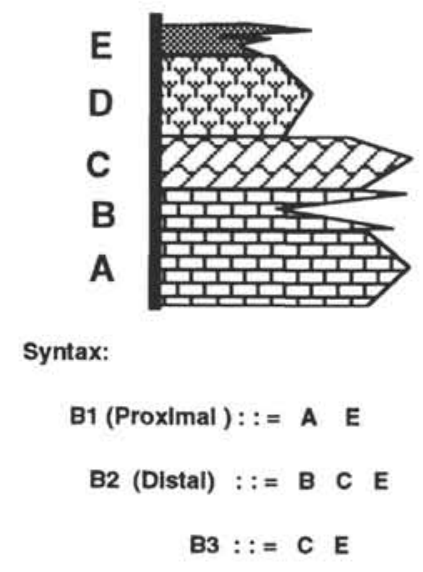

Figure 2. An ideal Bouma sequence.

has not been widespread. One of the reasons for this is the difficulty of reproducibly quantifying lithology from the more usual qualitative description of cores or hand specimens. Therefore, before starting to discuss sequence analysis, it is perhaps useful to consider the items that form the sequence. In this study, we use the term "lithostate" to include both particle-size based lithologies, and petrophysically defined "electrofacies" (Serra, 1977).

Sequences formed from core descriptions often contain a mixture of textural and structural terms, e.g., "laminated coarse carbonate." The wireline-log lithostates used here consist of combinations of log values alone, i.e., there are no textural components to the lithostate. Hand-specimen lithostates are determined at high resolution by visual inspection and optical microscopy, whereas wireline-log lithostates are derived from the log response at moderate resolution. Wireline-log values are effectively $0.3-$ to $0.6-\mathrm{m}$ moving averages sampled at intervals of 0.1 to $0.15 \mathrm{~m}$. Wirelinederived lithostates have an underdetermined relationship to handspecimen lithologies. Four or five petrophysical measurements cannot uniquely identify several hundred lithological unknowns. However, this is not necessarily a handicap if one does not attempt to convert the log data to lithologic data. The same sequence-analysis techniques can be used for both data sets, but one should be aware of the difference in resolution.

Appropriate sequence-analysis techniques include the following:

1. Frequency/sequency analysis using Fourier or Walsh transforms (Weedon, 1991; Weedon and Shimmield, 1989; Worthington, 1990).

2. Syntax analysis (Griffiths, 1989, 1990a, 1990b).

3. Transition probabilities (Vistelius, 1949).

Frequency/sequency analysis is useful for examining repetition in a sequence of continuous measurements (frequency) or lithostates (sequency). This method identifies the mean period of the repetitive segment, but is useful for predicting the actual states involved in the cycle. Syntax analysis offers a means of combining both statistical information and theoretical knowledge and may be developed from a conventional transition-probability analysis. Transition-probability analysis was applied here to both sets of lithostates (i.e., hand-specimen descriptors and wireline "electrofacies"). The technique has been described by many researchers since a geological application was demonstrated by Vistelius in 1949. Because the approach was first developed by A. A. Markov as part of a statistical analysis of Russian text, the identification of "Markov chains," or sequences in which any given state is partially dependent on one or more preceding states (i.e., is nonrandom), has been a relatively common procedure in sequence analysis. Here, the term "transition-probability" is used where the existence of a Markov chain has not (yet) been demonstrated. It is considered valid to discuss a Markov chain only once a significant dependency on a previous state or states has been proven. Discussions of the limitations and possibilities of Markov chains can be found in Griffiths (1966), Krumbein (1967), Selley (1970), Doveton (1971), Schwarzacher (1969; 1972), Miall (1973), Davis (1986), Walker (1979), Powers and Easterling (1982), Türk (1979), and Harper (1984).

Many technical problems are associated with the use of transition-probability analyses. One of the most basic problems is associated with the significance of observed transitions. To judge the significance, many workers have compared the observed transition matrix with a hypothetical random, independent, or quasiindependent matrix (see Goodman, 1968; Carr, 1982; Powers and Easterling, 1982). Different "randomness" measures give different significance, and each may be statistically or geologically justified under different circumstances and different degrees of sparseness of the matrix. It is not our purpose here to join in the discussion concerning appropriate randomness measures. The approach we adopted follows previously published lines (Harper, $1984)$ and is discussed in more detail in following sections.

\section{SITE 765 MIOCENE LITHOSTRATIGRAPHY AND SEDIMENTOLOGY}

The Miocene section at Site 765 is dominated by carbonates (Fig. 3) (Ludden, Gradstein, et al., 1990, pp. 76-83). The Miocene includes all or part of shipboard lithologic Subunits IC, IIA, IIB, IIC, and IIIA. This study is restricted to part of Subunit IC (147.3-189.1 mbsf), Subunit IIA (189.1-379 mbsf), and Subunit IIB (379-459.9 mbsf). The above lithologic subdivision was performed on the ship. Subdivision of the wireline logs into minimum-variance units was conducted on the shore and is discussed in a later section. 


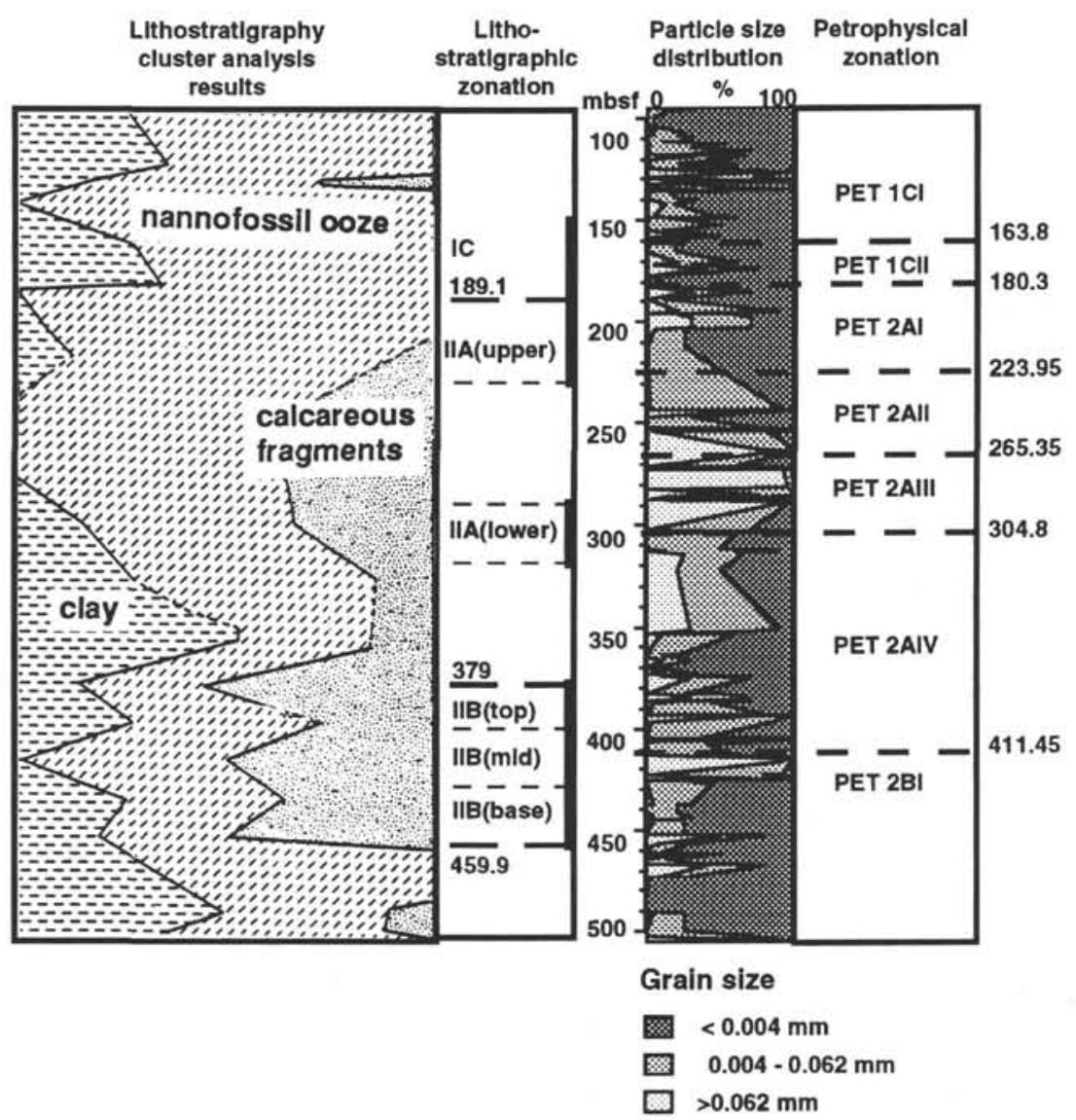

Figure 3. Site 765: Bulk mineralogy from cluster analysis results, lithostratigraphic, and petrophysical zonation for the Miocene section.

\section{Core Description}

\section{Subunit IC (147.3-189.1 mbsf)}

Several upward-fining, clayey, calcareous beds having minor amounts of silty clay overlie a quartzose base. The thicknesses of graded calcareous oozes vary from $\sim 350$ to $<5 \mathrm{~cm}$, but are more typically between 5 and $65 \mathrm{~cm}$ thick. These oozes are interbedded with 1- to 25-cm-thick silty clay layers and often include coarser basal oozes. These sediments have been interpreted as calcareous turbidites with thin intercalated pelagic and hemipelagic silty clays. The thickness and proportion of pelagic and hemipelagic components increases upward.

\section{Subunit IIA (189.1-379 mbsf)}

This subunit consists of a series of partially lithified upwardfining calcareous oozes and chalks that have been interpreted as redeposited turbidites. Bed thickness varies from 5 to $200 \mathrm{~cm}$.

\section{Subunit IIB (379-459.9 mbsf)}

This subunit consists of upward-fining, partially lithified, calcareous oozes (chalks). Textures include massive-to-planar laminae grading upward to thin, slightly inclined sets of cross-laminae and common convolute laminae. Bed thickness varies from 2 to $165 \mathrm{~cm}$. Intervals of interbedded claystone with $\leq 30 \%$ dolomite range from 6 to $35 \mathrm{~cm}$ thick. The thicker beds are found toward the base of the subunit. These sediments also have been interpreted as turbidites. The particle size of most graded units in this subunit is less than that in Subunit IIA. This suggests gradual progradation of the turbidite system throughout the Miocene
(Ludden, Gradstein, et al., 1990, p. 80). The turbidites are described as "predominantly moderately complete" with respect to a "Bouma Sequence" (Bouma, 1962), with the most common sequences being $\mathrm{BCDE}, \mathrm{BCD}$, and $\mathrm{CDE}$ (Ludden, Gradstein, et al., 1990, p. 95-98).

\section{Cluster Analysis of Compositional Data}

Q-mode cluster analysis of the smear-slide mineralogy data was conducted by one of us (MS) using a weighted pair group (average linkage) approach (Davis, 1986; Steinhausen and Langer, 1977; Schott, 1984). The relationship between cluster number and mineral content was then identified, and each sample was allocated a cluster identity. The relationship between the samples and cluster groups for short depth intervals (usually two or three cores) is displayed in Figure 3 as a mineral-proportion plot.

\section{Wireline Data}

The petrophysical logs used in this study were as follows:

1. Sonic $\log$ (DT): measuring the time taken for sound waves to pass through $30.48 \mathrm{~cm}(1 \mathrm{ft})$ of sediment.

2. Density (RHOB): measuring the bulk density of about a 30 -cm-length of the borehole wall.

3. Neutron porosity (NPHI): measuring the hydrogen content of a 30-cm-length of the borehole wall.

4. Potassium content $(\mathrm{K} \%)$ : the $1.46 \mathrm{MeV}$ window of natural gamma-ray radiation. 
These logs were originally recorded in the open hole at $0.5-\mathrm{ft}$ intervals. These depths have been converted to meters and resampled at equal $0.15-\mathrm{m}$ intervals. Our reason for choosing the potassium content is that the statistical precision of the $\mathrm{K} \%$ value (when measured over several replicate runs) is acceptable in this hole (Griffiths and Fuglestad, 1990). Uranium and thorium logs gave significantly lower precision.

Raw log curves were manually depth-matched, both with each other and with the physical-properties data to produce the best correlation coefficient from crossplots. Raw log curves were then blocked (Griffiths, 1982a) and subjected to principal-component analysis (PCA) using all four traces (2111 samples on 4 variables). Scores on the first eigenvector accounted for $53 \%$ of the variance. PCA scores on the first eigenvector then were subjected to a "minimum variance" global-optimum-zonation scheme (Hawkins and Merriam, 1973) using a modified and vectorized version of the "OPTZONE" program provided by John Birks (University of Bergen, Norway). This global optimum zonation took $400 \mathrm{~s}$ CPU time on a Cray XMP. Zonation was stopped at the level where adding a new zone accounted for less than $1 \%$ of the total variance in the section. Seven zones were produced using this technique. Note that only variance was used in this zonation, and many geological-unit boundaries were placed at shifts of both mean and variance. In addition, lithostratigraphic boundaries were often placed at shifts in variables that did not vary congruently with log-derived variables, which produced differences between the placement of petrophysical and lithostratigraphic boundaries.

Indeed, some differences do occur between petrophysicalzone boundaries and lithostratigraphic boundaries (Fig. 3). The petrophysical boundaries at 180.3 and 223.95 mbsf roughly coincide with the lithostratigraphic subdivisions. The petrophysicalzone boundary at 411.45 mbsf results from a significant change in log pattern that does not seem to have been evident during core description. All the "porosity" logs indicate a change at this point, and the proportion of clay-size material increases below $422 \mathrm{mbsf}$. Conversely, there seems to be no petrophysical reflection of the core-description boundary at 379 mbsf.

Figures 4 through 6 show the wireline-log traces, dominant particle sizes, and mineralogy for the Miocene section. Petrophysical sequence analysis has been applied within each of the petrophysical zones and has been related to the lithostratigraphic zonation.

\section{SEQUENCE ANALYSIS}

The main technique that we used is based on the number of transitions between lithostates, as observed in the section. The Bouma-sequence model is defined in terms of facies transitions, and the locations and times of lithostate transitions reflect the rate and magnitude of change of the depositional environment through time.

Seen in three dimensions, sediments are rarely deposited discretely, and commonly form part of a lateral continuum. The sharp discontinuities seen in vertical section, to some extent, form arbitrary subdivisions of the sequence. Even a few meters away from a given section, a sequence may be described by a different set of lithostates. The choice of lithostate-class boundary is thus of paramount importance in sequence analysis. The choice of too small a subdivision means that classes will not repeat anywhere in the sequence. If too broad a class is chosen, no vertical variation can be modeled. As discussed elsewhere (Griffiths, 1982b), the use of a data-based (idiographic) subdivision is dangerous because it inhibits comparison of results among studies and (usually) restricts the number of potential lithostates to between five and nine. The ideal is the traditional type of variable-based (ex- ogenous) subdivision (such as particle-size classes) that enables one to compare results from different studies without re-analyzing all the data.

The predictive efficiency of a classification in a transitionprobability model can be tested by calculating the information content of the system. The information content of a transition matrix was calculated as discussed in Shannon (1948) and Shannon and Weaver (1949). Specifically, we used the redundancy function calculated below.

First, we calculated Shannon's entropy function:

$$
H=-k \sum_{i=1}^{n}\left(p_{\mathrm{i}} \log p_{\mathrm{i}}\right),
$$

where $H=$ the entropy function of a series of $n$ independent events, $p_{\mathrm{i}}=$ the probability of occurrence of state, $i$, and $k$ is set to unity because we are interested only in relative entropy.

The maximum possible entropy is

$$
H_{\max }=\log N,
$$

where $N=$ the number of possible states in the sequence.

Relative entropy $H_{\mathrm{r}}$ is given by

$$
H_{\mathrm{r}}=H / H_{\max },
$$

and the first-order redundancy is

$$
R=1.0-H_{\mathrm{r}} .
$$

The second-order (transition) redundancy was also calculated as described in Shannon and Weaver (1949).

The term "redundancy" has a specific physical (and geological) meaning. If redundancy is equal to unity (or $100 \%$ ), then the system is completely determined, there is no freedom of choice, and knowing one state will enable the complete sequence to be reproduced without error. This is equivalent to being able to produce the complete works of Shakespeare from the first word, or the complete Miocene section at Site 765 from the lowest smear-slide description. However, a redundancy of zero implies a totally random distribution, with no predictability in the system at all. A classification offering good transition predictability is one that has a low first-order redundancy (i.e., not taking transitions into account) and a high second-order (transition) redundancy. In other words, such a classification will give an even spread of lithostates throughout the section and a transition matrix that is dominated by a few high probability transitions. Knowledge of the lithostate of a single sample thus permits one to predict the lithostates of vertically adjacent samples. The need for a low first-order redundancy combined with a high second-order redundancy can be explained as follows: although a high first-order redundancy (unity) can be achieved by designing a classification scheme that gives only one class in the section (e.g., "deep-sea sediment"), the resultant total predictability is of little stratigraphic use. These entropy functions were used to estimate the efficiency of the classification of the wireline-log data.

Another property of transition matrices, known as "ergodicity," is of interest here. Defined by Frechet (1938), an ergodic process is one in which "every sequence produced by the process is the same in statistical properties" (after Shannon, 1948). This may be interpreted as meaning that if one ran a sufficiently large number of Monte Carlo simulations of the sequence, then the resultant distribution statistics should be identical for each series 


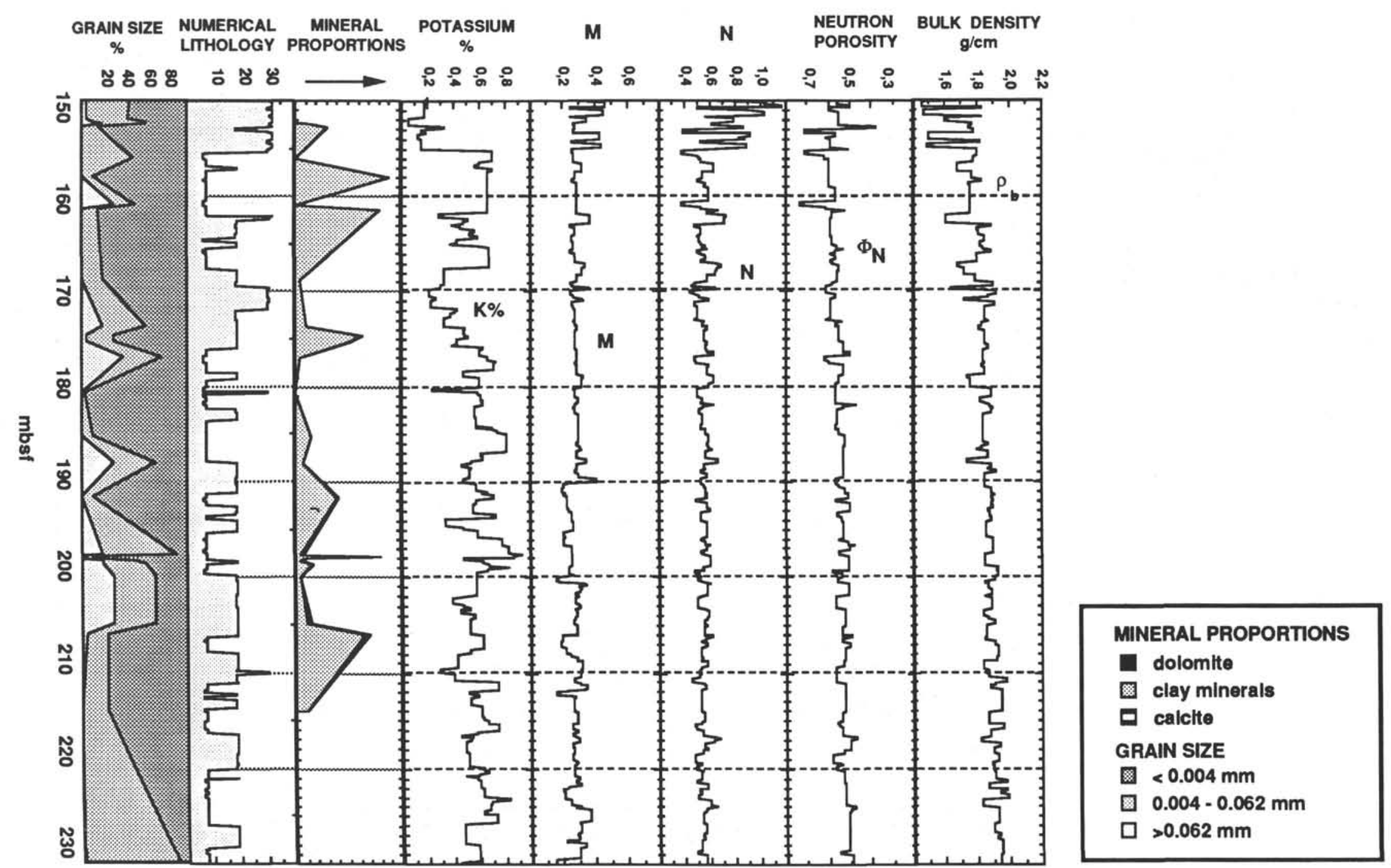

Figure 4. Wireline logs, mineralogy, and numerical lithologic sequence for lithologic Subunits IC and IIA(upper). 


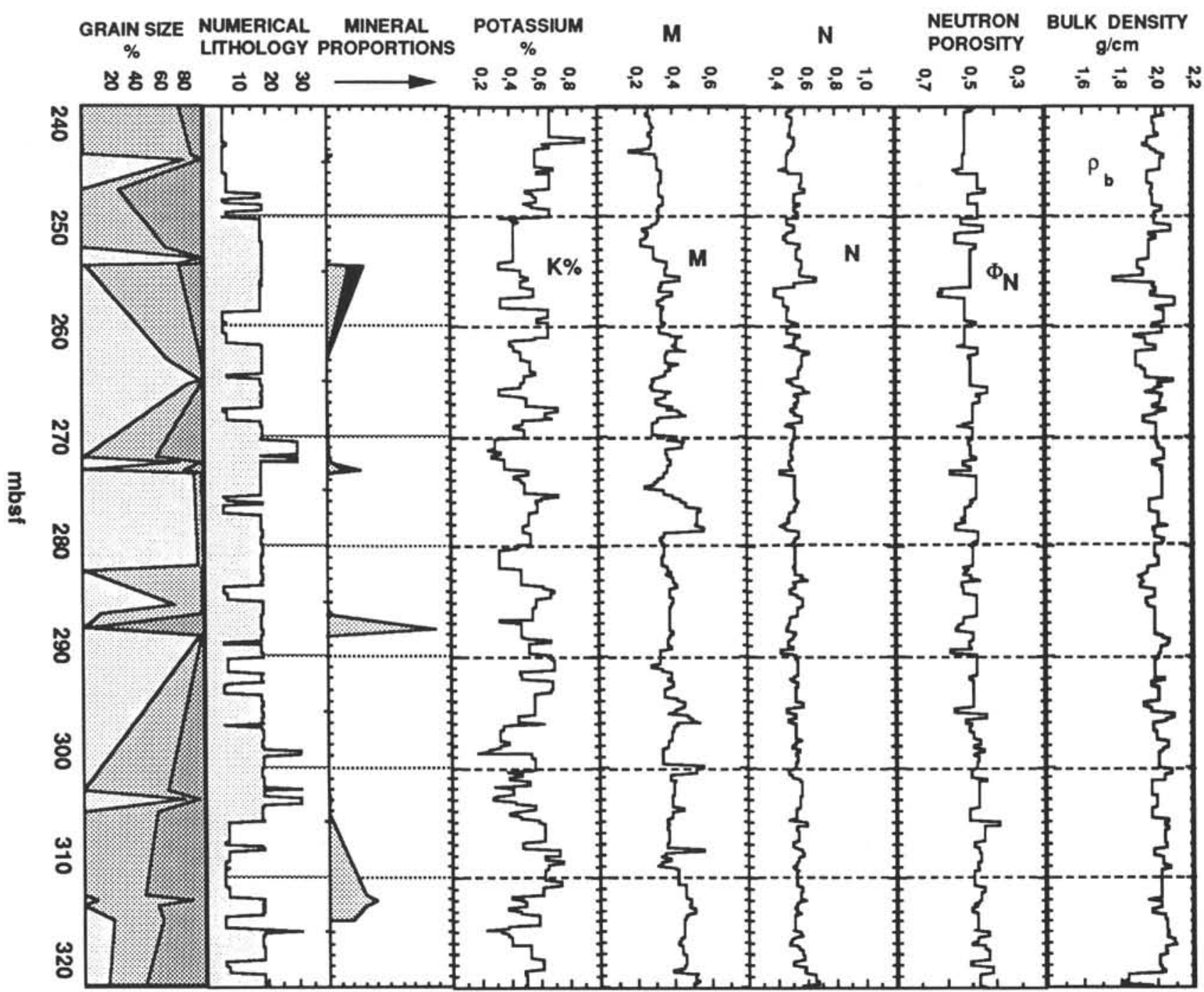

MINERAL PROPORTIONS

dolomite

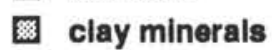

calcite

GRAIN SIZE

O $<0.004 \mathrm{~mm}$

$0.004-0.062 \mathrm{~mm}$

$\square>0.062 \mathrm{~mm}$

Figure 5. Wireline logs, mineralogy, and numerical lithologic sequence for lithologic Subunit IIA(lower). 


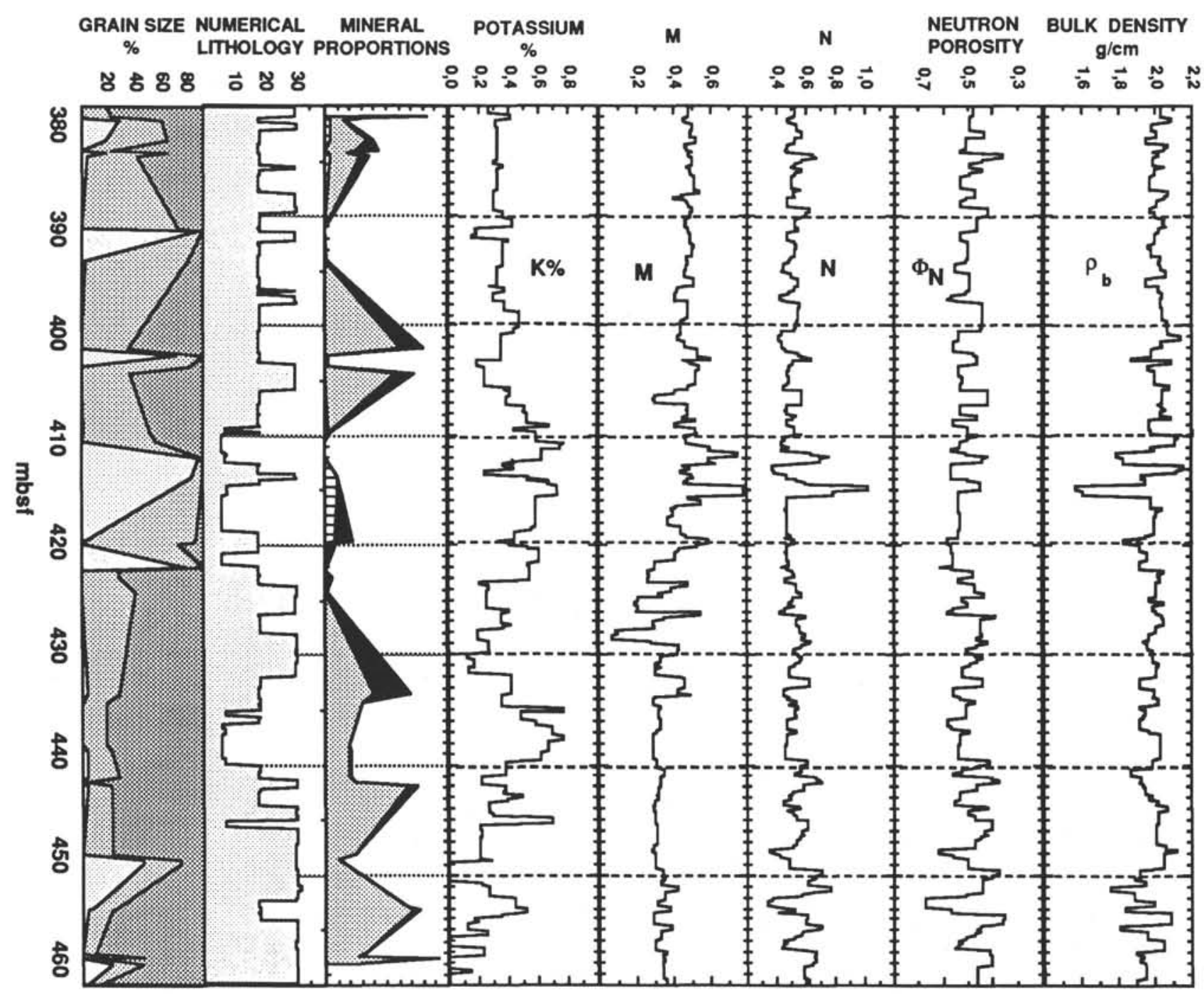

MINERAL PROPORTIONS

dolomite

圆 clay minerals

日 calcite

GRAIN SIZE

圆 $<0.004 \mathrm{~mm}$

$0.004-0.062 \mathrm{~mm}$

$\square>0.062 \mathrm{~mm}$

Figure 6. Wireline logs, mineralogy, and numerical lithologic sequence for lithologic Subunits IIB(top), IIB(middle), and IIB(bottom). 
of simulations. Two main requirements are necessary for an ergodic sequence:

1. The transition matrix does not consist of two or more isolated parts, such that it is impossible to reach one part from another.

2. Any closed series of transitions must have a common divisor of only unity.

It is primarily the first criterion that interests us here. Few of the Miocene transition matrices derived from wireline data are ergodic. Many of the significant transitions in the Miocene section occur in multiple loops, with only insignificant transitions between loops. Thus an attempt to simulate many of the Miocene subzone sequences using only significant transitions would end up being locked into one or another loop, with no chance of exit. This is typical of a chaotic system where two or more stable situations coexist, with the sedimentary sequence recording more or less frequent "flips" from one to the other. Such situations are found in river-channel systems, where the sedimentary sequence records periodic oscillation between channel-fill deposits and flood deposits. Thus, ergodicity is a useful additional measure of the periodic oscillatory nature of the recorded sequence.

\section{Core Description}

For the core-description facies, we used the original textural and structural exogenous classifications. The Miocene lithostratigraphic section was subdivided by one of us (DKM) into 12 sediment classes (as shown in Table 1). Note that Classes A through E parallel the Bouma-sequence identities.

\section{Wireline-Log Data}

The wireline-log data were classified as shown in Figure 7. The classification was designed according to the criteria discussed in the previous section, while considering the theoretical $\mathrm{N}$-value distribution. The $\mathrm{N}$-value is calculated as follows:

$$
N=\frac{\left(1.0-\phi_{\mathrm{N}}\right)}{\left(\rho_{\mathrm{b}}-1.0\right)},
$$

where $\emptyset_{\mathrm{N}}=$ the neutron porosity, and $\rho_{b}=$ the bulk density.

In this carbonate environment, the main variation in $\mathrm{N}$-value appears to be between dolomitic and/or shale components and calcareous components. We thus chose a class boundary of 0.52 as the major dividing line, with outer class divisions of 0.32 and 0.72 . For potassium, the class boundaries were chosen at a possible kaolinite/illite boundary of $0.57 \% \mathrm{~K}$ and a possible smectite/kaolinite boundary of $0.32 \% \mathrm{~K}$ (Hurst, 1990, p. 215). The potassium content of most clay minerals is not yet well understood, and the need for both more data and better statistical control on these data was discussed by Hurst (1990), who reviewed the

Table 1. Core description sediment classes.

\begin{tabular}{llcl}
\hline Class & \multicolumn{1}{c}{ Description } & Class & \multicolumn{1}{c}{ Description } \\
\hline A & Massive coarse carbonate & G & Siltstone \\
B & Laminated coarse carbonate & H & Sandstone \\
C & Cross-laminated coarse & I & Siliceous ooze \\
& $\quad$ carbonate & J & Carbonate conglomerate \\
D & Massive fine carbonate & K & Coal \\
E & Clay & L & Convolute coarse carbonate \\
F & Radiolarite & & \\
& & &
\end{tabular}

\section{Numerical lithology classes: with data from Site 765 Miocene section}

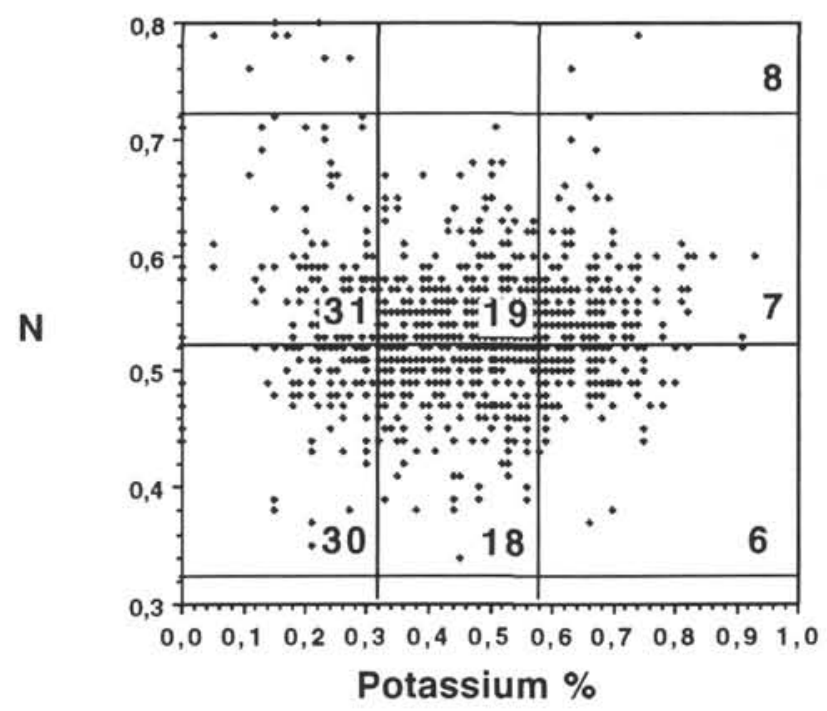

Figure 7. Wireline-log classes used for sequence analysis.

present state of gamma-ray spectrometry interpretation. Therefore, these class-boundary choices are to a certain extent arbitrary, but probably reflect systematic clay mineral changes.

\section{RESULTS AND DISCUSSION}

We used the randomness measure published by Walker (1979) for both the core-description and wireline sequences. The significance of observed transitions was then tested by the method proposed by Harper (1984), and cells that were not significant at the 0.1 level were dropped from the study. This significance level implies that one has a $<10 \%$ chance of interpreting wrongly a random transition as a significant one. No "multistory" lithologies were considered in the case of the core-description data. In other words, only transitions to and from differing facies were counted. This is known as an "embedded Markov chain model," and means that statistical information concerning the relative thickness of the various lithostates was during the analysis. In the case of the log data, all transitions were recorded, including "self-transitions," i.e., transitions within facies at the uniform sample spacing $(0.15$ $\mathrm{m})$. The resulting transition matrix is heavily biased toward the diagonal. To remove this bias, the matrix was reduced to its "zero-diagonal" or embedded Markov chain form, and the significance calculated from the zero-diagonal matrix. For the wireline$\log$ data, the transition matrices were then subjected to "substitutability analysis" (Davis and Cocke, 1972) to investigate the possibility of parallel transition structures.

A syntax was produced for each zone on the basis of the transition and substitution matrices. The construction of the syntax and its use in quantitative modeling and pattern recognition was discussed by Griffiths (1989, 1990a, and 1990b). The syntax is used directly to parse unknown sequences and is a useful means of not only summarizing a lithostratigraphic formation, but identifying complete subsequences within a zone. A syntax is a simple, but effective, means of describing, defining, or summarizing a sequence of symbols. Let us say, for example, that we have a series of facies descriptions that we have coded A, B, C, and D. We have noticed that $B$ always follows $A$, and that $C$ and D can substitute for each other after the A to B transition. Possible sequences are therefore A B C or A B D. These two alternatives 
comprise the total number of possible legal sequences in our environmental model. The syntax for this situation can be written in a "left substitution grammar," in what has come to be called the Bachus-Naur-Form (BNF). In this format, each series of symbols can be substituted by the symbol on the left, according to simple rules, as

$$
\begin{gathered}
\mathrm{S}::=\mathrm{T} 1 \mathrm{C} \mid \mathrm{T} 1 \mathrm{D}, \\
\text { T1 }::=\mathrm{A} \mathrm{B} .
\end{gathered}
$$

In the example above, we describe the transition $\mathrm{T} 1$ as being composed of facies A, followed by B. In other words, the sequence A B may be substituted by the nonterminal symbol T1 in our interpretation. The symbol $\mathrm{T} 1$ may be followed by either $\mathrm{C}$ or $\mathrm{D}$ to give a complete sequence, $\mathrm{S}$. The symbol $\mathrm{S}$ thus can substitute for either T1 C or T1 D. The vertical bar implies the existence of an alternative. The two-line grammar above thus neatly summarizes our model in an unambiguous and testable way. The BNF distinguishes between "terminal" symbols, which are our descriptors (e.g., sandstone, silt, ooze, etc.), and "nonterminal" symbols, which are successive layers of interpretation superimposed on the terminal symbols.

\section{Core-Description Data}

Tables 2 through 7 present the observed transition frequencies and the binomial probabilities for each transition. Note that the signed probabilities are merely a shorthand for indicating transi- tions greater than $(+v e)$ or less than $(-v e)$ expected and do not imply negative probabilities.

These tabular results are summarized in Figures 8 and 9. There are three components to each zone-sequence description. The first is the transition diagram showing the direction of significant lithostate transitions. The second is a pictorial representation of the facies involved, and the third is the appropriate syntax for those transitions.

The lowest part of the section (basal portion of Subunit IIB) is characterized by turbidites that begin with either cross-laminated or convolute silt-to-sand size carbonates. Massive coarse carbonates are notably absent. In the upper part of the cycle, the nannofossil ooze passes into clays. Transitions that do not occur are associated with energy transitions that are either too great or in the wrong direction. This should be reflected in jumps of more than one particle size (e.g., Facies A to E), or upward-coarsening transitions. The massive coarse carbonate does not become significantly involved in turbidite cycles until $\sim 420$ to $430 \mathrm{mbsf}$. Above this point, this carbonate commonly forms cycle bases up to $230 \mathrm{mbsf}$, where a siliciclastic component is introduced. From 190 to 230 mbsf (Subunit IIA upper), two nonergodic cycles occur. The siliciclastic cycle consists of an oscillation between quartzose sand and silt to clay, whereas the carbonate cycle consists of massive coarse carbonate and clay. Laminated carbonates and nannofossil ooze rarely substitute for clay in the upper part of the cycle.

Subunit IC is characterized by an ergodic mixed carbonate-siliciclastic turbidite cycle. The cycle base is formed by either quartzose sandstone (Facies $\mathrm{H}$ ) or massive coarse carbonate (Fa-

\begin{tabular}{|c|c|c|c|c|c|c|c|c|c|}
\hline & A & C & B & D & E & G & H & J & Row sum \\
\hline A & 0 & 1 & 12 & 59 & 9 & 2 & 2 & 0 & 85 \\
\hline & 0 & +0.29 & +0.03 & +0.00 & -0.00 & -0.47 & -0.13 & & \\
\hline C & 0 & $\begin{array}{c}1 \\
+0.06\end{array}$ & 0 & 0 & 0 & 0 & 0 & 0 & 1 \\
\hline B & $\begin{array}{c}1 \\
-0.02\end{array}$ & & & $\begin{array}{l}18 \\
-0.00\end{array}$ & $\begin{array}{c}0 \\
-0.00\end{array}$ & & & & 19 \\
\hline D & $\begin{array}{l}36 \\
-0.01\end{array}$ & & $\begin{array}{c}2 \\
-0.00\end{array}$ & & $\begin{array}{l}67 \\
+0.00\end{array}$ & $\begin{array}{l}3 \\
-0.32\end{array}$ & $\begin{array}{c}9 \\
+0.41\end{array}$ & $\begin{array}{c}3 \\
+0.40\end{array}$ & 120 \\
\hline E & $\begin{array}{l}37 \\
+0.01\end{array}$ & & $\begin{array}{c}3 \\
-0.14\end{array}$ & $\begin{array}{l}34 \\
-0.23\end{array}$ & & $\begin{array}{l}2 \\
-0.54\end{array}$ & $\begin{array}{l}2 \\
-0.17\end{array}$ & $\begin{array}{c}1 \\
-0.64\end{array}$ & 79 \\
\hline G & $\begin{array}{c}1 \\
-0.33\end{array}$ & & & $\begin{array}{c}5 \\
+0.13\end{array}$ & $\begin{array}{c}2 \\
+0.62\end{array}$ & & & & 8 \\
\hline H & $\begin{array}{c}9 \\
+0.00\end{array}$ & & $\begin{array}{c}1 \\
+0.58\end{array}$ & $\begin{array}{l}2 \\
-0.05\end{array}$ & $\begin{array}{c}1 \\
-0.10\end{array}$ & $\begin{array}{c}1 \\
+0.30\end{array}$ & & & 14 \\
\hline J & $\begin{array}{l}1 \\
-0.72\end{array}$ & & & $\begin{array}{c}2 \\
+0.47\end{array}$ & & & $\begin{array}{c}1 \\
+0.16\end{array}$ & & 4 \\
\hline Column sum & 85 & 1 & 19 & 120 & 79 & 8 & 14 & 4 & 330 \\
\hline
\end{tabular}

Table 2. Transition frequencies and probabilities, Subunit IC.

Table 3. Transition frequencies and probabilities, Subunit IIA (upper).

\begin{tabular}{lccccccc}
\hline & $\mathrm{A}$ & $\mathrm{C}$ & $\mathrm{D}$ & $\mathrm{E}$ & $\mathrm{G}$ & $\mathrm{H}$ & Row sum \\
\hline $\mathrm{A}$ & & 3 & 89 & 6 & 1 & 0 & 99 \\
$\mathrm{~B}$ & 1 & -0.49 & +0.00 & +0.00 & -0.18 & -0.02 & \\
& -0.25 & 0 & 5 & 0 & 0 & 0 & 6 \\
$\mathrm{D}$ & 73 & 1 & +0.06 & & & & \\
& +0.42 & -0.02 & & 29 & 1 & 5 & 109 \\
$\mathrm{E}$ & 21 & 1 & 11 & 0.23 & -0.12 & +0.44 & \\
& +0.04 & +0.61 & -0.03 & & +0.54 & +0.61 & 35 \\
$\mathrm{G}$ & 3 & & 2 & & & & 5 \\
H & +0.30 & 1 & -0.63 & & 2 & & 6 \\
& 1 & 1 & 2 & & 2 & \\
\multirow{2}{*}{ Column sum } & -0.25 & +0.13 & -0.48 & & +0.01 & & \\
& 99 & 6 & 109 & 35 & 5 & 6 & 260 \\
\hline
\end{tabular}


Table 4. Transition frequencies and probabilities, Subunit IIA (lower).

\begin{tabular}{|c|c|c|c|c|c|c|c|c|}
\hline & A & C & B & D & E & H & J & Row sum \\
\hline A & & $\begin{array}{c}6 \\
+0.19\end{array}$ & $\begin{array}{c}8 \\
-0.36\end{array}$ & $\begin{array}{l}29 \\
+0.04\end{array}$ & $\begin{array}{c}0 \\
-0.00\end{array}$ & 0 & 0 & 43 \\
\hline C & $\begin{array}{c}0 \\
-0.02\end{array}$ & & $\begin{array}{c}3 \\
+0.44\end{array}$ & $\begin{array}{l}10 \\
+0.02\end{array}$ & & & & 13 \\
\hline B & $\begin{array}{c}0 \\
-0.0\end{array}$ & $\begin{array}{c}1 \\
-0.24\end{array}$ & & $\begin{array}{l}31 \\
+0.0\end{array}$ & & & & 32 \\
\hline D & $\begin{array}{l}32 \\
+0.31\end{array}$ & $\begin{array}{c}5 \\
-0.11\end{array}$ & $\begin{array}{l}16 \\
-0.08\end{array}$ & & $\begin{array}{l}19 \\
+0.05\end{array}$ & $\begin{array}{c}2 \\
+0.40\end{array}$ & $\begin{array}{c}2 \\
+0.40\end{array}$ & 76 \\
\hline E & $\begin{array}{l}10 \\
+0.01\end{array}$ & $\begin{array}{c}1 \\
-0.56\end{array}$ & $\begin{array}{c}4 \\
+0.50\end{array}$ & $\begin{array}{c}4 \\
-0.03\end{array}$ & & & & 19 \\
\hline H & $\begin{array}{c}1 \\
+0.41\end{array}$ & & $\begin{array}{c}1 \\
+0.32\end{array}$ & & & & & 2 \\
\hline J & & & & $\begin{array}{c}2 \\
+0.17\end{array}$ & & & & 2 \\
\hline Column sum & 43 & 13 & 32 & 76 & 19 & 2 & 2 & 187 \\
\hline
\end{tabular}

Table 5. Transition frequencies and probabilities, Subunit IIB (top).

\begin{tabular}{lcccccccc}
\hline & $\mathrm{A}$ & $\mathrm{C}$ & $\mathrm{B}$ & $\mathrm{D}$ & $\mathrm{E}$ & $\mathrm{L}$ & $\mathrm{K}$ & Row sum \\
\hline $\mathrm{A}$ & & 4 & 3 & 14 & 3 & & & 24 \\
& & +0.12 & -0.34 & +0.05 & +0.12 & & & 13 \\
$\mathrm{C}$ & 1 & & 5 & 7 & 0 & & & \\
& -0.45 & & +0.06 & +0.17 & -0.01 & & & 30 \\
$\mathrm{~B}$ & 3 & 2 & & 23 & 0 & 2 & & \\
& -0.32 & -0.55 & & +0.00 & -0.00 & +0.17 & 1 & 66 \\
$\mathrm{D}$ & 7 & 1 & 8 & & 48 & 1 & 1 \\
& -0.04 & -0.01 & -0.01 & & +0.00 & -0.36 & +0.42 & \\
$\mathrm{E}$ & 12 & 5 & 13 & 20 & & 1 & & 51 \\
& +0.16 & +0.53 & +0.31 & -0.14 & & -0.56 & & 4 \\
$\mathrm{~L}$ & 1 & 1 & 2 & & & & 4 \\
K & 1 & +0.25 & +0.51 & +0.45 & & & & 1 \\
& & & & & & & & 1 \\
Column sum & 24 & 13 & 30 & 66 & 51 & 4 & 1 & 189 \\
\hline
\end{tabular}

Table 6. Transition frequencies and probabilities, Subunit IIB (middle).

\begin{tabular}{lccccccc}
\hline & $\mathrm{A}$ & $\mathrm{C}$ & $\mathrm{B}$ & $\mathrm{D}$ & $\mathrm{E}$ & $\mathrm{L}$ & Row sum \\
\hline $\mathrm{A}$ & & 3 & 2 & 11 & 2 & & 18 \\
& & +0.28 & -0.50 & +0.06 & -0.03 & & \\
$\mathrm{C}$ & 0 & & 3 & 23 & 1 & 2 & 29 \\
& -0.13 & & -0.33 & +0.00 & -0.00 & +0.10 & \\
$\mathrm{~B}$ & 1 & 8 & & 28 & 2 & 2 & 41 \\
& -0.21 & +0.08 & & +0.00 & -0.00 & +0.20 & \\
$\mathrm{D}$ & 4 & 7 & 13 & & 88 & 0 & 112 \\
& -0.01 & -0.00 & -0.00 & & +0.00 & -0.05 & \\
$\mathrm{E}$ & 13 & 8 & 23 & 48 & & 1 & 93 \\
$\mathrm{~L}$ & +0.06 & -0.08 & +0.15 & -0.31 & & -0.33 & \\
& & 3 & & 2 & 0 & & 5 \\
& & +0.01 & & +0.63 & -0.15 & & \\
Column sum & 18 & 29 & 41 & 112 & 93 & 5 & 298 \\
\hline
\end{tabular}

cies A). Those cycles having sandy bases are thought to represent higher energy turbidites than those having carbonate bases.

The overall impression given by the core-description sequence analysis is of multiple changes in depositional conditions from middle to late Miocene, leading to significant changes in cycle composition. The full Bouma sequence is rarely developed, but pair oscillation is common. The sequence has some of the characteristics of a gradual progression from more distal (at the base of the section) to more proximal (at the top), ending with a return to a more distal setting, but this might also be influenced by a change in source material, as more siliciclastics are present in the upper section. Obvious erosive features are uncommon (Ludden, Gradstein, et al., 1990, pp. 79-83). The site may have received scattered bursts of sediment from turbidity currents that largely by- passed the site. This might account for the presence of the pelagic/hemipelagic component as a significant part of all cycles, but with varying coarser fractions included at different times to reflect both changes in source material and energy.

\section{Wireline-Log Data}

The transitions involved in the wireline zones are summarized in Tables 8 through 14. The petrophysical sequences can be seen in Figures 10 through 12. Each wireline-log-zone sequence description consists of three parts:

1. A pictorial facies relationship to show grouping of lithostates according to the results of substitutability analysis and their significant transitions. 
Table 7. Transition frequencies and probabilities, Subunit IIB (bottom).

\begin{tabular}{|c|c|c|c|c|c|c|c|}
\hline & A & $\mathrm{C}$ & B & D & E & L & Row sum \\
\hline A & & $\begin{array}{c}1 \\
-0.55\end{array}$ & $\begin{array}{c}4 \\
+0.16\end{array}$ & $\begin{array}{l}10 \\
+0.11\end{array}$ & $\begin{array}{c}1 \\
-0.01\end{array}$ & $\begin{array}{c}1 \\
+0.31\end{array}$ & 17 \\
\hline C & $\begin{array}{c}1 \\
-0.53\end{array}$ & & $\begin{array}{c}2 \\
-0.34\end{array}$ & $\begin{array}{l}22 \\
+0.00\end{array}$ & $\begin{array}{c}0 \\
-0.00\end{array}$ & & 25 \\
\hline B & $\begin{array}{c}0 \\
-0.09\end{array}$ & $\begin{array}{c}5 \\
+0.26\end{array}$ & & $\begin{array}{l}29 \\
+0.00\end{array}$ & $\begin{array}{c}0 \\
-0.00\end{array}$ & $\begin{array}{c}2 \\
+0.20\end{array}$ & 36 \\
\hline D & $\begin{array}{c}6 \\
-0.08\end{array}$ & $\begin{array}{c}8 \\
-0.02\end{array}$ & $\begin{array}{c}5 \\
-0.00\end{array}$ & & $\begin{array}{l}97 \\
+0.00\end{array}$ & $\begin{array}{c}0 \\
-0.02\end{array}$ & 116 \\
\hline E & $\begin{array}{l}10 \\
+0.32\end{array}$ & $\begin{array}{l}11 \\
-0.42\end{array}$ & $\begin{array}{l}24 \\
+0.07\end{array}$ & $\begin{array}{l}50 \\
-0.10\end{array}$ & & $\begin{array}{c}3 \\
+0.57\end{array}$ & 98 \\
\hline L & & & $\begin{array}{c}1 \\
+0.55\end{array}$ & $\begin{array}{c}5 \\
+0.04\end{array}$ & $\begin{array}{l}0 \\
-0.09\end{array}$ & & 6 \\
\hline Column sum & 17 & 25 & 36 & 116 & 98 & 6 & 298 \\
\hline
\end{tabular}

2. The syntax relating to this zone.

3 . The result of using the syntax to parse the sequence between the zone boundaries, i.e., a sequence interpretation.

The symbols $\mathrm{kN}, \mathrm{KN}, \mathrm{Kn}$, and so forth, in the pictorial representation refer to low, medium, and high potassium classes, as Kn, $\mathrm{KN}$, and $\mathrm{KN}$, refer to low, medium, and high $\mathrm{N}$ values. Thus both the facies number and the symbols refer to locations in the $\mathrm{K}$ through $\mathrm{N}$ crossplot in Figure 7. The syntax is derived as described in the preceding section. Observed, significant facies substitutions are denoted by ALT1 and ALT2, and so forth, while significant transitions are labeled T1, T2, and so forth. The complete sequence model for Subunit PET 1CI is identified as S1CI.

The parsed sequence shows the result of applying a "left-substitution parser" to the complete facies sequence observed in the relevant zone. This parser attempts to substitute all facies with higher-order symbols. For example, in Subunit PET 1CI, both Facies 18 or 31 would be replaced in the list by ALT1. If the new symbol ALT1 were followed by Facies 32 somewhere in the sequence, then the pair ALT1 32 would be replaced by the symbol T1. In turn, this would be replaced by S1CI, and the conditions for a legal sequence would have been fulfilled at that position in Subunit PET 1CI. Referring to Figure 10, the facies sequence from 140 to 163.8 mbsf (Subunit PET 1CI) consists of the interpreted sequence ALT2 ALT1 ALT2 S1CI 8 S1CI 30 S1CI 303230 S1CI $3032 \mathrm{~S} 1 \mathrm{CI}$ from base to top. This shows that the observed sequence of facies fits our statistically significant model at five places within the section. In addition to this, a number of facies do not fit our model for one reason or another. It may be that the model is not sufficient, or it may be that the model sequence has been disturbed by events that are in themselves not significant; they appear as disturbances to the "ideal," statistically significant model.

As mentioned in a previous section, the wireline lithostates do not commonly translate unambiguously to core-description lithostates. In fact, the thicknesses of units identified using wireline logs are comparable to the thicknesses of entire turbidites, or sequences of turbidites, identified by core analysis. Hence, individual wireline lithostates may roughly correspond to turbidites or groups of turbidites. Variations in thickness of units identified using wireline-logs may echo thickness variation of turbidites or groups of turbidites. This variation is a product of depositional thicknesses, possible truncation, and compaction. Thus, cycles observed in wireline-log data may correspond to small-scale cycles of the order of the thickness of several turbidites. Just as with the Bouma sequences observed in core data, thicker sequences composed of stacked turbidites may be truncated by erosion, and they may be studied in exactly the same way. Here, we address the problem of completeness of the section as a means of distinguishing sediment starvation from other possible causes of low average sedimentation rates in a turbidite section.

Within each petrophysical subunit, the transition and substitution matrices form the basis from which a statistically significant syntax describing the subunit is developed. This syntax is then used within the subunit to "parse" the section itself. The resulting interpretation tests both the adequacy of the syntax and the completeness of the section. An inadequate syntax will leave gaps in interpretation that themselves have structure (i.e., have predictable relations to the existing syntax). However, an incomplete section will leave gaps in interpretation that have only a random relationship to the existing syntax. Looking at the parsed sequences in turn, as displayed in Figures 10 through 12, the base of the section from 465 to 411 mbsf shows that the syntax managed to identify 26 complete cycles. Only a few lithostates are not accounted for by the syntax, and these have an irregular distribution. Subunit IIB (PET 2BI) thus would seem to consist largely of predictable sediment sequences.

The result of parsing Subunit PET 2AIV shows an example of an inadequate syntax. The transitions T1 ALT1 and T1 ALT2 occur too frequently to be random, and thus the syntax should be modified accordingly. However, even without modifying the syntax, we can see that the sequence can be explained in terms of a defined structure that is different from the structure in the underlying subunit.

The remaining subunits show a similar story; although differences exist, the syntax manages to explain most of the structure in the section. Subunit PET 1CI has a somewhat different problem in that a nonsignificant lithostate 30 occurs sporadically and disrupts the main sequence. Here, the syntax has managed to identify only four complete cycles or (in this case) sets of cycles. Substitution is common within the cycles, but only in certain directions. Substitution never occurs with a neighboring class, only with a diagonally related class, such as (referring to Fig. 7) 19 and 6 , or 18 and 7 .

\section{SUMMARY}

Core-description sequence analyses show that the quantitative use of transition probabilities can identify significant sediment cyclicities and lend support to environmental hypotheses suggested by initial core description. Wireline data, with their continuous lower resolution measurements, can be used to quantitatively examine predictable structures in the sequence and, via parsing, can be used to investigate the completeness and location of higher-order cycles than those observed in core. Wireline-unit thicknesses approximate turbidite thicknesses, although thin turbidites cannot be resolved by the wireline logs used here. There- 


\section{Subunit IC 147.3 - 189.1 mbsf}

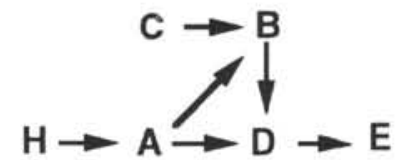

Syntax:
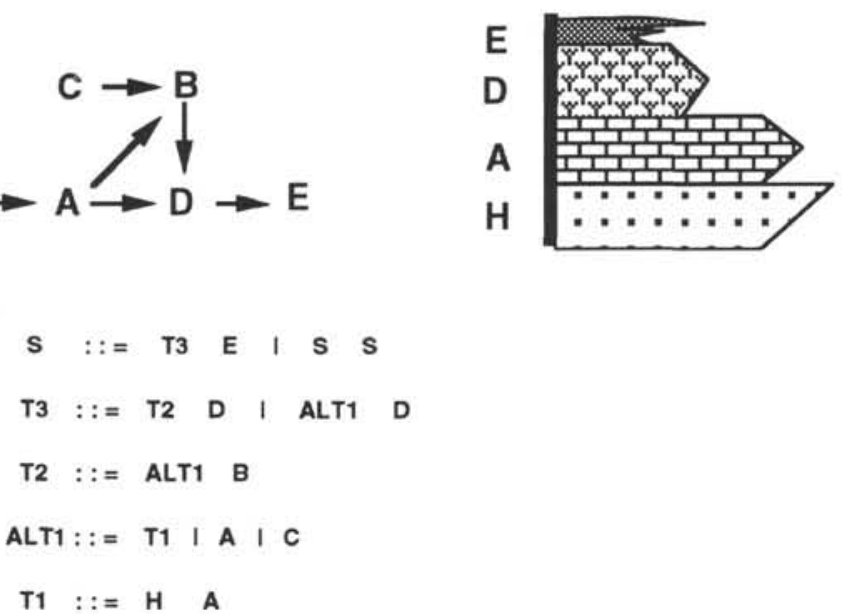

Subunit IIA (upper) $\quad$ 189.1-230.0 mbsf

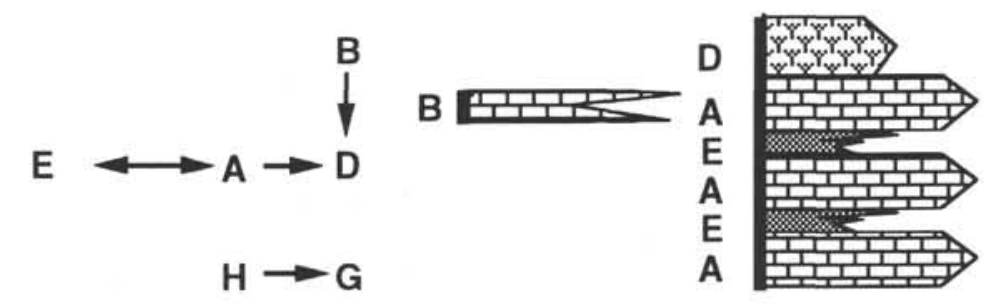

Syntax:
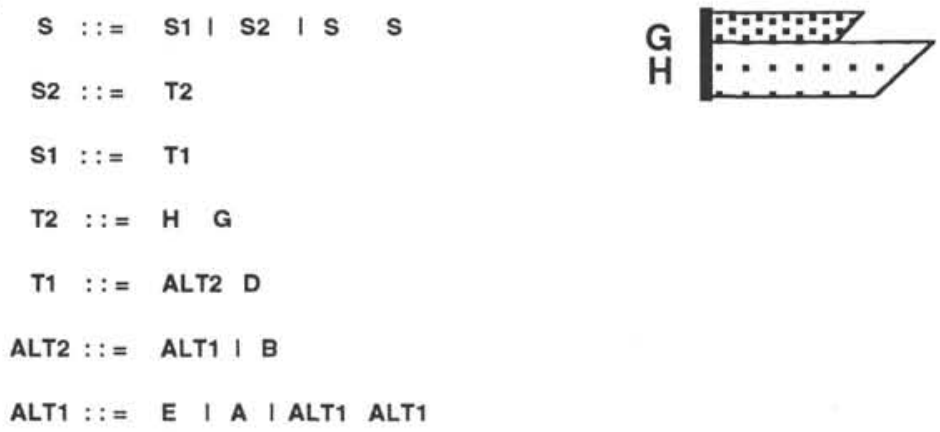

Figure 8. Core description sequences and syntax: lithologic Subunits IC, IIA(upper), and IIA(lower).

fore, wireline data may express variation in thickness and composition (mineralogical, textural, and fabric) of turbidite sequences.

We have shown how appropriate syntaxes can be developed from both wireline and core-description data. Our conclusion from the combined analyses is that, with few exceptions, each subunit consists of statistically significant sequences of lithostates. Transition patterns exhibit multiple loops. Random gaps in the sequences are uncommon. These observations support either a sediment-starvation hypothesis (with periodic change of source giving the substitutability) or a hypothesis of bypassing with scattered deposition of different material in the area, but with repeatable energy regimes. Such situations are found in riverchannel systems, where the sedimentary sequence records peri- odic oscillation between channel-fill deposits and flood deposits. The prevalence of this kind of multiple-loop transition pattern in Miocene sequences at Site 765 suggests that the submarine-fan system that deposited these sediments may also have exhibited this kind of periodic oscillatory behavior. This, in turn, suggests that the Miocene fan-system at Site 765 was channeled, a conclusion supported by the abundance of coarse turbidites that lack fine divisions (Walker, 1979; see Kopaska-Merkel, this volume). Thus, the analysis of core-description data indicates that most turbidite sequences are relatively complete, and therefore erosion is not supported as the cause of the low average sedimentation rate. The analysis of the wireline data is complementary, because the cycles investigated are of a higher order. Analysis of the 
wireline data suggests that higher-order cyclicity may result from periodic oscillation between two or more styles of sediment deposition.

\section{ACKNOWLEDGMENTS}

This study was supported by grants from the Norwegian Council for Scientific Research (NAVF), the Nordic Council, and USSAC. Significant improvements resulted from comments by John Doveton and Dorrik Stow, who reviewed the paper.

\section{REFERENCES}

Bouma, A. H., 1962. Sedimentology of Some Flysch Deposits: Amsterdam (Elsevier).

Bouma, A. H., Stelting, C. E., and Coleman, F., 1985. Mississippi Fan, Gulf of Mexico. In Bouma, A. H., Normark, W. R., and Barnes, N. E. (Eds.), Submarine Fans and Related Turbidite Systems:. New York (Springer-Verlag).

Carr, T. R., 1982. Log-linear models, Markov chains and cyclic sedimentation. J. Sediment. Petrol., 52:3:905-912.

Davis, J. C., 1986. Statistics and Data Analysis in Geology (2nd. ed.): New York (Wiley and Sons).

Davis, J. C., and Cocke, J. M., 1972. Interpretation of complex lithologic successions by substitutability analysis. In Merriam, D. F. (Ed.), Mathematical Models of Sedimentary Processes: New York (Plenum Press), 27-52.

Doveton, J. H., 1971. An application of Markov chain analysis to the Ayrshire coal measures succession. Scott. J. Geol., 7(1):11-27.

Frechet, M., 1938. Methods des fonction arbitraires. Theorie des enenemants en chaine dans le cas d'un nombre fini d'etats possible: Paris (Gauthier-Villars).

Goodman, L. A., 1968. The analysis of cross-classified data: independence, quasi-independence, and interactions in contingency tables with or without missing entries. J. Am. Statist. Assoc. 63:1091-1131.

Griffiths, C. M., 1982a. A proposed geologically consistent segmentation and reassignment algorithm for petrophysical borehole logs. In Cubitt, J. M., and Reyment, R. A. (Eds.), Quantitative Stratigraphic Correlation: London (Wiley and Sons), 287-298.

1982b. Pigeonholes and petrography. Computer applications in geology III. Geol. Soc. London, Misc. Pap. 15. Reprinted in Handbook of Geophysical Exploration, Sect. 1, Seismic Exploration, Helbig, K., and Treitel, S. (Eds), 1987, 20: London (Geophysical Press), 539-557. 1989. The nature of the geological representation language and consequent constraints on machine interpretation. In Simaan, M., and Aminzadeh, F. (Eds.), Advances in Geophysical Data Processing, 3: Bridgeport (JAI Press), 49-77.

1990a. Choice of lithology identifiers for modelling purposes in quantitative stratigraphy. In Cross, T. A. (Ed.), Quantitative Dynamic Stratigraphy: Englewood Cliffs, NJ (Prentice-Hall), 67-88. 1990b. The language of rocks: an example of the use of syntactic analysis in the interpretation of sedimentary environments from wireline-logs. In Hurst, A., Lovell, M. A., and Morton, A. C. (Eds.), Geological Applications of Wireline-Logs. Geol. Soc. London Spec. Publ., 48:77-94.

Griffiths, C. M., and Fuglestad, O., 1990. Shale discrimination using logs. Proc. 2nd Seminar on Petroleum Geology and Claystone Problems (University of Oslo, Norway, 25 January 1990). (Abstract only).

Griffiths, J. C., 1966. Future trends in geomathematics. Pennsylvania State Univ., Mineral Industries, 35:1-8.

Harper, C. W., 1984. Improved methods of facies sequence analysis. In Walker, R. G. (Ed.), Facies Models. Geosci. Can. Reprint Ser. 1 (2nd ed.), Geol. Assoc. Can., 11-13.

Hawkins, D. M., and Merriam, D. F., 1973. Optimal zonation of digitized sequential data. J. Math. Geol., 5(4):389-395.

Hurst, A., 1990. Natural gamma-ray spectrometry in hydrocarbon-bearing sandstones from the Norwegian Continental Shelf. In Hurst, A.,
Lovell, M. A., and Morton, A. C. (Eds.), Geological Applications of Wireline-Logs. Geol. Soc. London, Spec. Publ., 48:211-222.

Kolla, V., and Coumes, F., 1985. Indus Fan, Indian Ocean. In Bouma, A. H., Normark, W. R., and Barnes, N. E. (Eds.), Submarine Fans and Related Turbidite Systems: New York (Springer-Verlag).

Krumbein, W. C., 1967. FORTRAN IV computer programs for Markov chain experiments in geology. Kansas Geol. Surv. Computer Contr., $13: 38$.

Ludden, J. N., Gradstein, F. M., et al., 1990. Proc. ODP, Init. Repts., 123: College Station, TX (Ocean Drilling Program).

Miall, A. D., 1973. Markov chain analysis applied to an ancient alluvial plain succession. Sedimentology, 20(3):347-364.

Powers, D. W., and Easterling, R. G., 1982. Improved methodology for using embedded Markov chains to describe cyclical sediments. J. Sed. Petrol., 52(3):913-923.

Schott, M., 1984. Mikrofaziell-multivariate analyse einer rhato-liassischen karbonatplattform in den Nordlichen Kalkalpen. Facies, 11:229-280.

Schwarzacher, W., 1969. The use of Markov chains in the study of sedimentary cycles. J. Int. Assoc. Math. Geol., 1(1):17-39. 1972. The semi-Markov process as a general sedimentation model. In Merriam, D. F. (Ed.), Mathematical Models of Sedimentary Processes: New York (Plenum Press), 247.

Selley, R. C., 1970. Studies of sequence in sediments using a simple mathematical device. Quart. J. Geol. Soc. London, 125:557-581.

Serra, O., 1977. Méthode rapide d'analyse faciologique par diagraphies differées. S.P.W.L.A., 5th Europ. Symp. Trans. (Paris), Pap. 9.

Shanmugam, G., Moiola, R. J., Damuth, J. E., 1985. Eustatic control of submarine fan development. In Bouma, A. H,. Normark, W. R., and Barnes, N. E. (Eds.) Submarine Fans and Related Turbidite Systems: New York (Springer-Verlag), 23-28.

Shannon, C. E., 1948. A mathematical theory of communication. Tech. J. Bell Lab., 27:379-423.

Shannon, C. E., and Weaver, W., 1949. The Mathematical Theory of Communication: Urbana, IL (Univ. of Illinois Press).

Steinhausen, D., and Langer, K., 1977. Clusteranalyse: Berlin (De Gruyter).

Türk, G., 1979. Transition analyses of structural sequences: discussion and reply. Geol. Soc. Am. Bull., 90(I):989-992.

Vistelius, A. B., 1949. K voprosu o mechanizme sloeobrazovania (On the question of the mechanism of the formation of strata). Dokl. Akad. Nauk S.S.S.R., 65(2):191-194.

von Rad, U., and Exon, N. F., 1982. Mesozoic-Cenozoic sedimentary and volcanic evolution of the starved passive continental margin off northwest Australia. In Watkins, J. S., and Drake, C. L. (Eds.), Studies in Continental Margin Geology. AAPG Mem., 34:253-281.

Walker, R. G. (Ed.), 1979. Facies Models. Geosci. Can. Reprint Ser. 1, Geol. Assoc. Can.

Weedon, G. P., 1991. The spectral analysis of stratigraphic time series. In Einsele, G., Selacher, A., and Ricken, W. (Eds.), Cyclic and Event Stratification (2nd ed.): Berlin (Springer-Verlag).

Weedon, G. P., and Shimmield, G. B., 1989. Late Pleistocene upwelling and productivity variations in the northwest Indian ocean deduced from spectral analysis of geochemical data from Sites 722 and 724 . In Prell, W. L., Niitsuma, N., et al., Proc. ODP, Sci. Results, 117: College Station, TX (Ocean Drilling Program), 431-443.

Worthington, P. F., 1990. Sediment cyclicity from well logs. In Hurst, A., Lovell, M. A., and Morton, A. C. (Eds.), Geological Applications of Wireline-Logs. Geol. Soc. London Spec. Publ., 48:123-132.

Date of initial receipt: 25 June 1990

Date of acceptance: 28 May 1991

Ms 123B-153 
Subunit IIA (lower) 290 - 320 mbsf
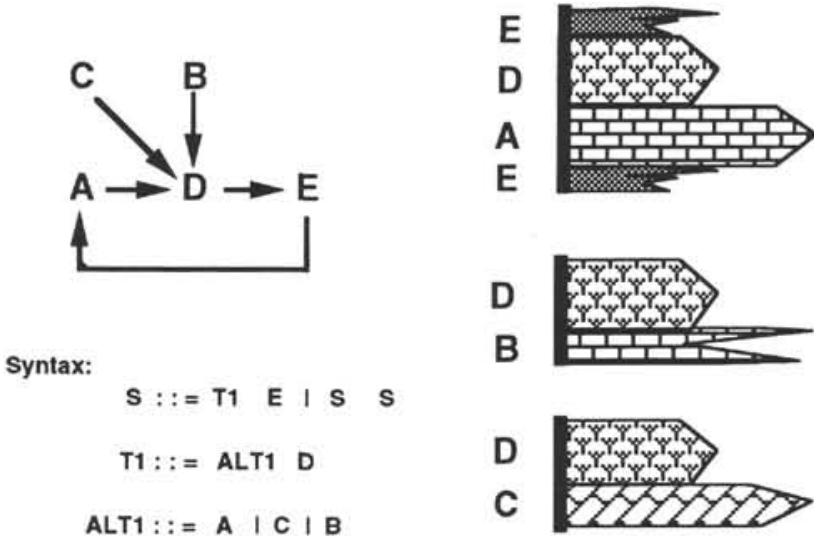

Subunit IIB (top) $379-400$ mbsf
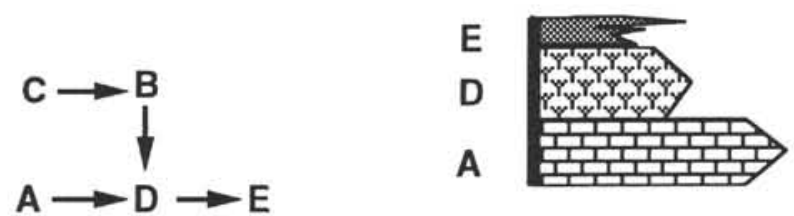

Syntax:

$$
\begin{aligned}
\text { S }:: & =\text { T2 E IS S } \\
\text { T2 }:: & =\text { ALT1 D } \\
\text { ALT1 }:: & =\text { T1 I A } \\
\text { T1 }:: & =\text { C B }
\end{aligned}
$$

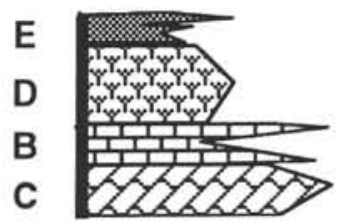

Figure 9. Core description sequences and syntax: lithologic Subunits IIA (lower), IIB(top), IIB(middle), and IIB(bottom). 
Subunit IIB (middle) 400 - 430 mbsf
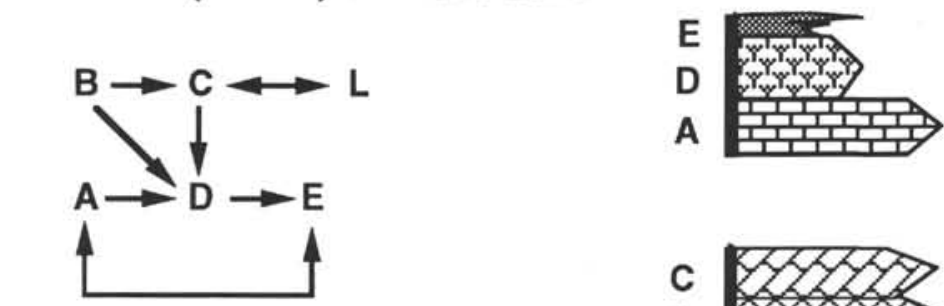

Syntax:

$$
\begin{aligned}
\text { S }:: & =\text { T1 } E \text { |S } S \\
\text { T1 }:: & =\text { ALT1 D } \\
\text { ALT1 }:: & =B \text { C I B IA IL C }
\end{aligned}
$$

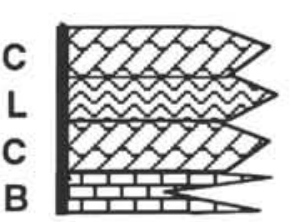

Subunit IIB (bottom) 430 - 460 mbsf

$$
\begin{aligned}
\text { Syntax: } & \\
\text { S }: & :=\text { T1 } \text { E IS } S \\
\text { T1 }:: & =\text { ALT1 D } \\
\text { ALT1 }:: & =\text { L I B |C }
\end{aligned}
$$

Figure 9 (continued).

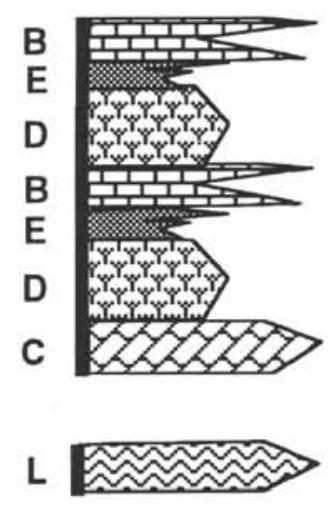




\section{M. GRIFFITHS, D. C. KOPASKA-MERKEL, M. SCHOTT}

Table 8. Transition frequencies, probabilities and entropies: wireline-log zone PET 1CI.

\begin{tabular}{|c|c|c|c|c|c|c|c|c|c|}
\hline \multicolumn{10}{|c|}{$\begin{array}{l}\text { Wireline-log zone: PET } 1 \mathrm{CI}(140.00-163.80 \mathrm{mbsf}) \\
\text { Transition frequency matrix with signed probabilities }\end{array}$} \\
\hline & 32 & 31 & 30 & 18 & 6 & 7 & 19 & 8 & \\
\hline 32 & 31 & $\begin{array}{l}5 \\
0.14\end{array}$ & $\begin{array}{l}3 \\
0.22\end{array}$ & & & & $\begin{array}{c}1 \\
-0.38\end{array}$ & $\begin{array}{l}1 \\
0.35\end{array}$ & 41 \\
\hline 31 & 7 & 4 & & & & & & & 11 \\
\hline 30 & $\begin{array}{l}2 \\
0.40\end{array}$ & $\begin{array}{l}1 \\
0.65\end{array}$ & 3 & $\begin{array}{l}1 \\
0.24\end{array}$ & & & & & 7 \\
\hline 18 & $\begin{array}{l}1 \\
0.43\end{array}$ & & & 2 & & & $\begin{array}{l}1 \\
0.17\end{array}$ & & 4 \\
\hline 6 & & & $\begin{array}{l}1 \\
0.34\end{array}$ & & 6 & $\begin{array}{l}2 \\
0.04\end{array}$ & & & 9 \\
\hline 7 & & & & & $\begin{array}{l}3 \\
0.00\end{array}$ & 28 & $\begin{array}{l}1 \\
0.34\end{array}$ & & 32 \\
\hline 19 & & $\begin{array}{l}1 \\
0.52\end{array}$ & & $\begin{array}{l}1 \\
0.18\end{array}$ & & $\begin{array}{l}1 \\
0.34\end{array}$ & 6 & & 9 \\
\hline 8 & & & & & & $\begin{array}{l}1 \\
0.12\end{array}$ & & & 1 \\
\hline $\begin{array}{l}\text { Total samples } \\
\text { Total transitions }\end{array}$ & 41 & 11 & 7 & 4 & 9 & 32 & 9 & 1 & 114 \\
\hline
\end{tabular}

Transition probability matrix after removal of insignificant transitions

\begin{tabular}{|c|c|c|c|c|c|c|c|c|c|}
\hline & 32 & 31 & 30 & 18 & 6 & 7 & 19 & 8 & Relative thickness \\
\hline 32 & & & & & & & & & 31.0 \\
\hline 31 & 1.00 & & & & & & & & 0.57 \\
\hline 30 & & & & & & & & & 3.0 \\
\hline 18 & & & & & & & & & 2.0 \\
\hline 6 & & & & & & 1.00 & & & 3.0 \\
\hline 7 & & & & & 1.00 & & & & 9.33 \\
\hline 19 & & & & & & & & & 6.0 \\
\hline 8 & & & & & & & & & 1.0 \\
\hline
\end{tabular}

Note: Effective resolution $=0.15 \mathrm{~m}$; total first-order entropy $=1.686$; total second-order entropy $=0.270 ; \mathrm{H}_{\max }(8)$ $=2.079$; non-Markov redundancy $=18.9 \%$; second-order redundancy $=87.0 \%$; zero-diagonal non-Markov redundancy $=18.9 \%$; zero-diagonal second-order redundancy $=100.0 \%$.

Table 9. Transition frequencies, probabilities and entropies: wireline-log zone PET 1CII.

Wireline-log zone: PET 1 CII (163.80-180.30 mbsf)

Transition frequency matrix with signed probabilities

\begin{tabular}{|c|c|c|c|c|c|c|c|c|}
\hline & 19 & 18 & 6 & 7 & 31 & 30 & & \\
\hline 19 & 34 & $\begin{array}{l}2 \\
0.31\end{array}$ & $\begin{array}{l}2 \\
0.47\end{array}$ & $\begin{array}{l}2 \\
0.61\end{array}$ & & & 40 & \\
\hline 18 & $\begin{array}{l}2 \\
0.20\end{array}$ & 10 & & & & $\begin{array}{l}1 \\
0.28\end{array}$ & 13 & \\
\hline 6 & & $\begin{array}{l}1 \\
0.52\end{array}$ & 7 & $\begin{array}{l}3 \\
0.06\end{array}$ & & & 11 & \\
\hline 7 & $\begin{array}{l}3 \\
0.23\end{array}$ & & $\begin{array}{l}2 \\
0.34\end{array}$ & 26 & & & 31 & \\
\hline 31 & $\begin{array}{l}1 \\
0.42\end{array}$ & & & & 3 & $\begin{array}{l}1 \\
0.18\end{array}$ & 5 & \\
\hline 30 & & & & & 2 & 9 & 11 & \\
\hline $\begin{array}{l}\text { Total samples } \\
\text { Total transitions }\end{array}$ & 40 & 13 & 11 & 31 & 5 & 11 & 111 & 22 \\
\hline
\end{tabular}

Transition probability matrix after removal of insignificant transitions

\begin{tabular}{|c|c|c|c|c|c|c|c|}
\hline & 19 & 18 & 6 & 7 & 31 & 30 & Relative thickness \\
\hline 19 & & & & & & & 14.57 \\
\hline 18 & & & & & & & 4.29 \\
\hline 6 & & & & 1.00 & & & 1.0 \\
\hline 7 & & & & & & & 11.14 \\
\hline 31 & & & & & & & 1.29 \\
\hline 30 & & & & & 1.00 & & 1.93 \\
\hline
\end{tabular}

Note: Effective resolution $=0.35 \mathrm{~m}$; total first-order entropy $=1.601$; total second-order entropy $=0.228 ; \mathrm{H}_{\max }(6)=1.792 ;$ non-Markov redundancy $=10.6 \%$; second-order redundancy $=$ $87.3 \%$; zero-diagonal non-Markov redundancy $=10.6 \%$; zero-diagonal second-order redundancy $=100.0 \%$ 
Table 10. Transition frequencies, probabilities and entropies: wirelinelog zone PET 2AI.

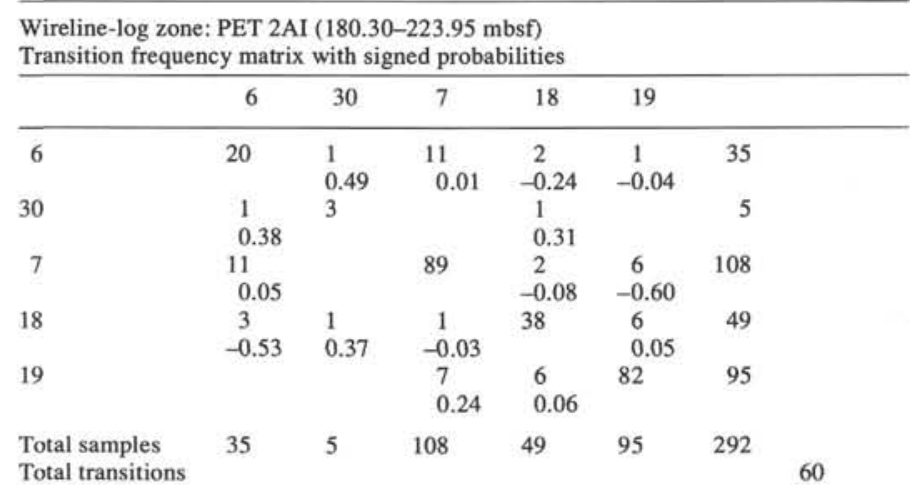

Transition probability matrix after removal of insignificant transitions

\begin{tabular}{rcccccc}
\hline & 6 & 30 & 7 & 18 & 19 & Relative thickness \\
\hline 6 & & & 1.00 & & & 1.00 \\
30 & & & & & & 1.80 \\
7 & 1.00 & & & & & 4.11 \\
18 & & & & \multirow{2}{*}{1.00} & & 8.26 \\
19 & & & & &
\end{tabular}

Note: Effective resolution $=0.27 \mathrm{~m}$; total first-order entropy $=1.345$; total second-order entropy $=0.472 ; \mathrm{H}_{\max }(5)=1.609$; non-Markov redundancy $=16.4 \%$; second-order redundancy $=70.7 \%$; zero-diagonal non-Markov redundancy $=16.4 \%$; zero-diagonal second-order redundancy $=100.0 \%$.

Table 11. Transition frequencies, probabilities and entropies: wireline-log zone PET 2AII.

\begin{tabular}{|c|c|c|c|c|c|c|}
\hline \multicolumn{7}{|c|}{$\begin{array}{l}\text { Wireline-log zone: PET } 2 \text { AII ( } 223.95-265.35 \text { mbsf) } \\
\text { Transition frequency matrix with signed probabilities }\end{array}$} \\
\hline & 7 & 19 & 6 & 18 & & \\
\hline 7 & 54 & $\begin{array}{c}4 \\
-0.42\end{array}$ & $\begin{array}{l}8 \\
0.01\end{array}$ & $\begin{array}{c}1 \\
-0.03\end{array}$ & 67 & \\
\hline 19 & $\begin{array}{l}5 \\
0.54\end{array}$ & 77 & & $\begin{array}{l}7 \\
0.07\end{array}$ & 89 & \\
\hline 6 & $\begin{array}{l}5 \\
0.19\end{array}$ & $\begin{array}{c}1 \\
-0.12\end{array}$ & 54 & $\begin{array}{l}3 \\
0.55\end{array}$ & 63 & \\
\hline 18 & $\begin{array}{c}3 \\
-0.33\end{array}$ & $\begin{array}{l}7 \\
0.05\end{array}$ & $\begin{array}{c}1 \\
-0.13\end{array}$ & 47 & 58 & \\
\hline $\begin{array}{l}\text { Total samples } \\
\text { Total transitions }\end{array}$ & 67 & 89 & 63 & 58 & 277 & 45 \\
\hline
\end{tabular}

Transition probability matrix after removal of insignificant transitions

\begin{tabular}{rccccc}
\hline & 7 & 19 & 6 & 18 & Relative thickness \\
\hline 7 & & & 1.00 & & 1.00 \\
19 & & & & 1.00 & 1.83 \\
6 & \multirow{3}{*}{1.00} & & & 9.00 \\
18 & & & & 1.12 \\
\hline
\end{tabular}

Note: Effective resolution $=1.01 \mathrm{~m}$; total first-order entropy $=1.371 ;$ total second-order entropy $=0.559 ; \mathrm{H}_{\max }(4)=1.386$; non-Markov redundancy $=1.1 \%$; second-order redundancy $=59.7 \%$; zero-diagonal non-Markov redundancy $=1.1 \%$; zero-diagonal second-order redundancy $=100.0 \%$. 
Table 12. Transition frequencies, probabilities and entropies: wireline-log zone PET 2AIII.

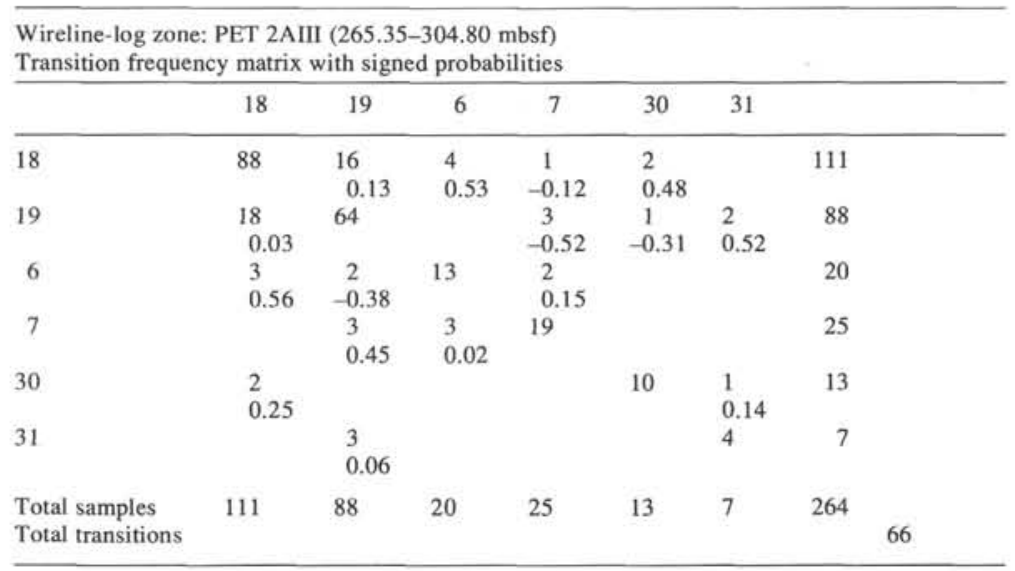

Transition probability matrix after removal of insignificant transitions

\begin{tabular}{|c|c|c|c|c|c|c|c|}
\hline & 18 & 19 & 6 & 7 & 30 & 31 & Relative thickness \\
\hline 18 & & & & & & & 66.00 \\
\hline 19 & 1.00 & & & & & & 2.67 \\
\hline 6 & & & & & & & 9.75 \\
\hline 7 & & & 1.00 & & & & 4.75 \\
\hline 30 & & & & & & & 7.50 \\
\hline 31 & & 1.00 & & & & & 1.00 \\
\hline
\end{tabular}

Note: Effective resolution $=0.20 \mathrm{~m}$; total first-order entropy $=1.396$; total second-order entropy $=0.301 ; \mathrm{H}_{\max }(6)=1.792$; non-Markov redundancy $=22.1 \%$; second-order redundancy $=$ $83.2 \%$; zero-diagonal non-Markov redundancy $=22.1 \%$; zero-diagonal second-order redundancy $=100.0 \%$.

Table 13. Transition frequencies, probabilities and entropies: wireline-log zone PET 2AIV.

\begin{tabular}{|c|c|c|c|c|c|c|c|c|}
\hline \multicolumn{9}{|c|}{$\begin{array}{l}\text { Wireline-log zone: PET } 2 \text { AIV ( } 304.80-411.45 \mathrm{mbsf}) \\
\text { Transition frequency matrix with signed probabilities }\end{array}$} \\
\hline & 18 & 19 & 7 & 6 & 31 & 30 & & \\
\hline 18 & 145 & $\begin{array}{l}28 \\
0.00\end{array}$ & & $\begin{array}{l}5 \\
0.56\end{array}$ & $\begin{array}{l}3 \\
-0.09\end{array}$ & $\begin{array}{l}5 \\
-0.48\end{array}$ & 186 & \\
\hline 19 & $\begin{array}{l}31 \\
0.00\end{array}$ & 194 & $\begin{array}{c}4 \\
-0.25\end{array}$ & & $\begin{array}{l}8 \\
0.48\end{array}$ & $\begin{array}{ll}2 \\
-0.03\end{array}$ & 239 & \\
\hline 7 & & $\begin{array}{l}6 \\
0.29\end{array}$ & 38 & 7 & & & 51 & \\
\hline 6 & $\begin{array}{c}2 \\
-0.20\end{array}$ & $\begin{array}{c}1 \\
-0.04\end{array}$ & $\begin{array}{l}9 \\
0.00\end{array}$ & 52 & & & 64 & \\
\hline 31 & $\begin{array}{c}1 \\
-0.01\end{array}$ & $\begin{array}{l}8 \\
0.18\end{array}$ & & & 85 & $\begin{array}{l}7 \\
0.00\end{array}$ & 101 & \\
\hline 30 & $\begin{array}{l}7 \\
0.13\end{array}$ & $\begin{array}{c}2 \\
-0.08\end{array}$ & & & $\begin{array}{l}5 \\
0.02\end{array}$ & 57 & 71 & \\
\hline $\begin{array}{l}\text { Total samples } \\
\text { Total transitions }\end{array}$ & 186 & 239 & 51 & 64 & 101 & 71 & 712 & 141 \\
\hline
\end{tabular}

Transition probability matrix after removal of insignificant transitions

\begin{tabular}{rccccccc}
\hline & 18 & 19 & 7 & 6 & 31 & 30 & Relative thickness \\
\hline 18 & & 1.00 & & & & & 1.00 \\
19 & 1.00 & & & & & & 1.26 \\
7 & & & \multirow{2}{*}{1.00} & & & & 1.16 \\
6 & & & & & & 1.00 & 1.11 \\
31 & & & & & 1.00 & & 1.74 \\
30 & & & & & & \\
\hline
\end{tabular}

Note: Effective resolution $=0.78 \mathrm{~m}$; total first-order entropy $=1.620$; total second-order entropy $=$ $0.673 ; \mathrm{H}_{\max }(6)=1.792$; non-Markov redundancy $=9.6 \%$; second-order redundancy $=62.4 \%$; zero-diagonal non-Markov redundancy $=9.6 \%$; zero-diagonal second-order redundancy $=$ $100.0 \%$. 
Table 14. Transition frequencies, probabilities and entropies: wireline-log zone PET 2BI.

\begin{tabular}{|c|c|c|c|c|c|c|c|c|c|c|}
\hline \multicolumn{11}{|c|}{$\begin{array}{l}\text { Wireline-log zone: PET 2BI ( } 411.45-465.00 \mathrm{mbsf}) \\
\text { Transition frequency matrix with signed probabilities }\end{array}$} \\
\hline & 6 & 7 & 8 & 19 & 18 & 30 & 31 & 32 & & \\
\hline 6 & 43 & $\begin{array}{l}1 \\
0.44\end{array}$ & $\begin{array}{l}1 \\
0.17\end{array}$ & & $\begin{array}{l}2 \\
0.30\end{array}$ & & $\stackrel{1}{-0.41}$ & & 48 & \\
\hline 7 & $\begin{array}{l}3 \\
0.01\end{array}$ & 14 & & $\begin{array}{c}1 \\
-0.35\end{array}$ & & & $\begin{array}{c}1 \\
-0.38\end{array}$ & & 20 & \\
\hline 8 & & $\begin{array}{l}1 \\
0.19\end{array}$ & 6 & & & & & & 8 & \\
\hline 19 & & $\begin{array}{l}3 \\
0.27\end{array}$ & & 33 & $\begin{array}{l}8 \\
0.01\end{array}$ & $\begin{array}{c}1 \\
-0.20\end{array}$ & $\begin{array}{c}2 \\
-0.24\end{array}$ & & 47 & \\
\hline 18 & $\begin{array}{l}2 \\
0.36\end{array}$ & & & $\begin{array}{l}8 \\
0.01\end{array}$ & 44 & $\begin{array}{l}2 \\
0.62\end{array}$ & & & 56 & \\
\hline 30 & & & & & $\begin{array}{l}1 \\
-0.29\end{array}$ & 41 & $\begin{array}{l}7 \\
0.00\end{array}$ & & 49 & \\
\hline 31 & & $\begin{array}{c}1 \\
-0.35\end{array}$ & & $\begin{array}{l}4 \\
0.48\end{array}$ & $\begin{array}{c}1 \\
-0.13\end{array}$ & $\begin{array}{l}5 \\
0.04\end{array}$ & 81 & $\begin{array}{l}1 \\
0.22\end{array}$ & 93 & \\
\hline 32 & & & & & & & $\begin{array}{l}1 \\
0.20\end{array}$ & 2 & 3 & \\
\hline $\begin{array}{l}\text { Total samples } \\
\text { Total transitions }\end{array}$ & 48 & 20 & 8 & 47 & 56 & 49 & 93 & 3 & 324 & 60 \\
\hline
\end{tabular}

Transition probability matrix after removal of insignificant transitions

\begin{tabular}{|c|c|c|c|c|c|c|c|c|c|}
\hline & 6 & 7 & 8 & 19 & 18 & 30 & 31 & 32 & Relative thickness \\
\hline 6 & & & & & & & & & 21.50 \\
\hline 7 & 1.00 & & & & & & & & 2.33 \\
\hline 8 & & & & & & & & & 3.00 \\
\hline 19 & & & & & 1.00 & & & & 2.06 \\
\hline 18 & & & & 1.00 & & & & & 2.75 \\
\hline 30 & & & & & & & 1.00 & & 2.93 \\
\hline 31 & & & & & & 1.00 & & & 8.10 \\
\hline 32 & & & & & & & & & 1.00 \\
\hline
\end{tabular}

Note: Effective resolution $=0.30 \mathrm{~m}$; total first-order entropy $=1.816$; total second-order entropy $=0.436 ; \mathrm{H}_{\mathrm{max}}(8)$ $=2.079$; non-Markov redundancy $=12.7 \%$; second-order redundancy $=79.0 \%$; zero-diagonal non-Markov redundancy $=12.7 \%$; zero-diagonal second-order redundancy $=100.0 \%$. 


\section{Subunit PET $1 \mathrm{Cl}$ ( 140.0 TO 163.8 mbsf )}

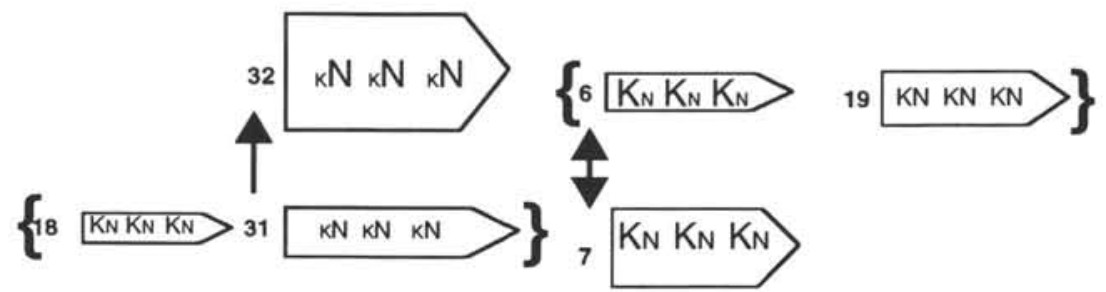

Syntax:

$$
\begin{aligned}
& \mathrm{s} 1 \mathrm{Cl}::=\mathrm{T} 1|\mathrm{~T} 2| \mathrm{s} 1 \mathrm{Cl} \mathbf{s} 1 \mathrm{Cl} \\
& \text { T2 : : = } 7 \text { ALT2 |ALT2 } 7 \\
& \text { T1 : : = ALT1 } 32
\end{aligned}
$$

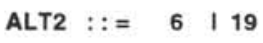

$$
\begin{aligned}
& \text { ALT1 }::=18 \quad \mid 31
\end{aligned}
$$

Parsed Sequence :

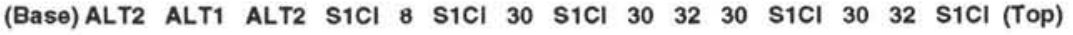

\section{Subunit PET 1CII ( 163.8 TO 180.3 mbsf )}

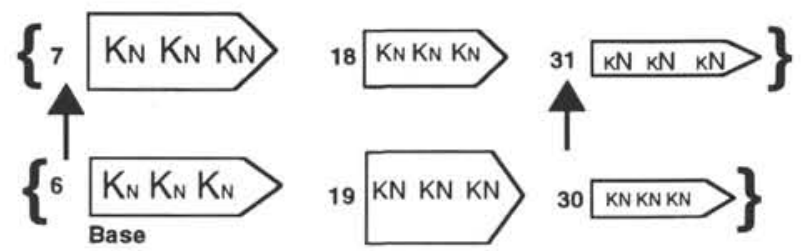

Syntax:

$$
\begin{aligned}
& \text { S1CI }::=\text { ALT1 ALT2 | S1C\| S1CI } \\
& \text { ALT2 }::=\begin{array}{lllll}
78 & \mid 31 \\
\text { ALT1 }::=6 & \mid 19 & \mid 30
\end{array}
\end{aligned}
$$

\section{Parsed Sequence:}

(Base) S1CII ALT1 S1CII ALT1 (Top)

Figure 10. Wireline-log sequences and syntax: wireline Subunits PET 1CI, PET 1CII. 


\section{Subunit PET 2AI ( 180.3 TO 223.95 mbsf)}

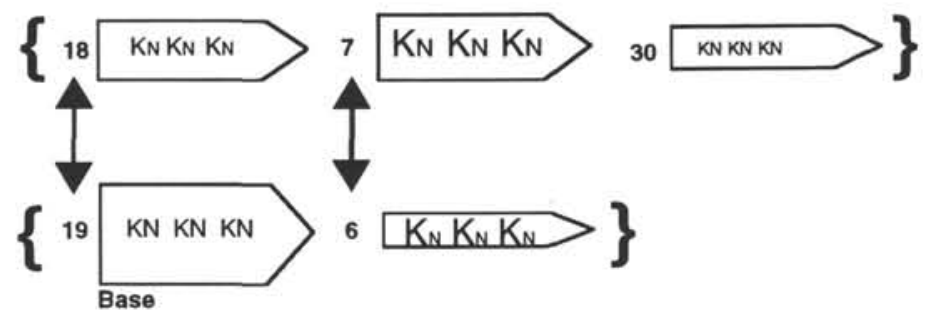

Syntax:

S2AI : := ALT1 ALT2 I ALT2 ALT1

ALT2 : : $=\begin{array}{lllll}18 & \mid & 7 & \mid & 30\end{array}$

ALT1 : : = 19 | 6

Parsed Sequence:

(Base) S2AI S2AI S2AI S2AI S2AI S2AI ALT2 S2AI S2AI S2AI S2AI S2AI ALT2 S2AI S2AI S2AI (TOP)

\section{Subunit PET 2All (223.95 TO 265.35 mbsf )}

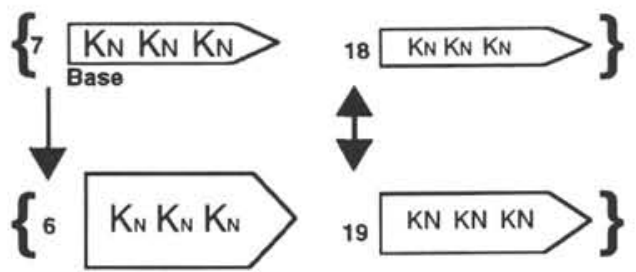

Syntax:

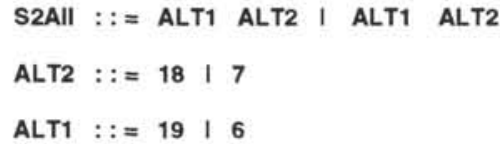

Figure 11. Wireline-log sequences and syntax: wireline Subunits PET 2AI and PET 2AII. 


\section{Subunit PET 2Alll (265.35 TO 304.8 mbsf)}

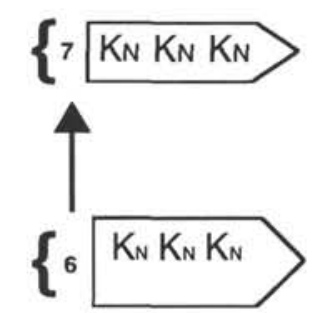

Syntax:
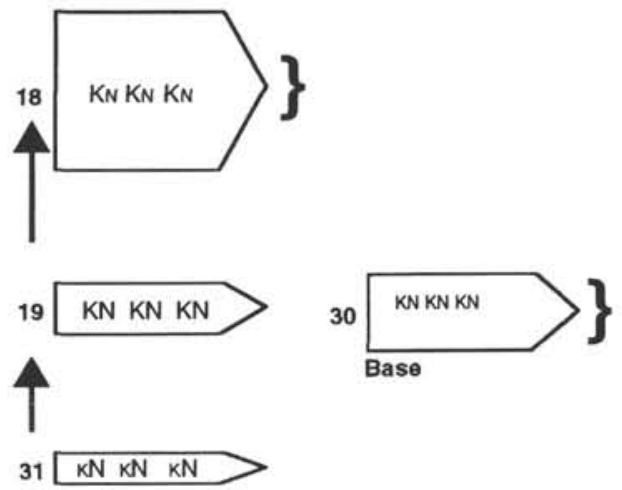

S2AIII $::=31$ T1

T1 : : = ALT1 ALT2

ALT2 $::=7$ । 18

ALT1 : : = 6 | 19 | 30

Parsed Sequence:

(Base) ALT2 ALT1 31 ALT1 S2AIII ALT1 ALT1 S2AIII T1 ALT1 T1 ALT1 T1 ALT2 T1 ALT1 (Top)

\section{Subunit PET 2AIV ( 304.8 TO 411.45 mbsf )}

Syntax:

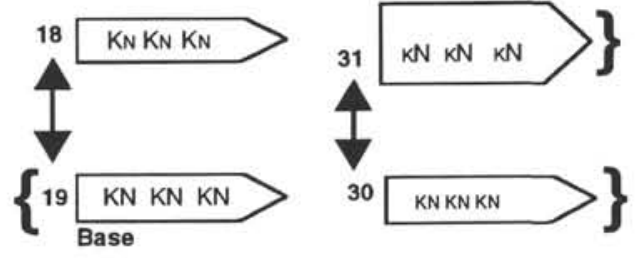

$$
\begin{aligned}
& \text { S2AIV : : = } \begin{array}{lllll}
T 1 & 6 & 1 & 6 & T 1
\end{array} \\
& \text { T1 : := ALT1 ALT2 I ALT2 ALT1 } \\
& \text { ALT2 }::=\begin{array}{lllll}
7 & \mid & 18 & \mid & 31
\end{array} \\
& \text { ALT1 : : = } 19 \text { | } 30
\end{aligned}
$$

Parsed Sequence:

(Base) S2AIV T1 ALT1 T1 ALT1 T1 ALT1 ALT1 T1 ALT2 S2AIV S2AIV T1 ALT2 S2AIV S2AIV S2AIV S2AIV S2AIV S2AIV S2AIV ALT2 (TOP)

Figure 12. Wireline-log sequences and syntax: wireline Subunits PET 2AIII, PET 2AIV, and PET 2BI. 
Subunit PET 2BI ( 411.45 TO 465.0 mbsf )

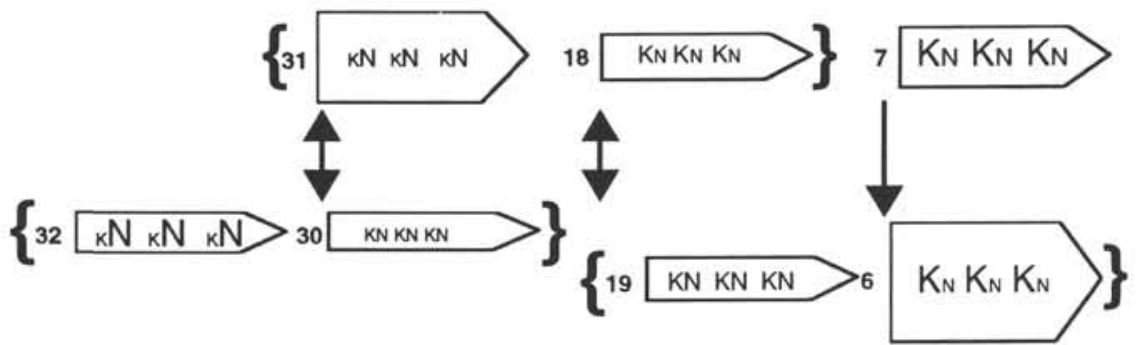

Syntax:

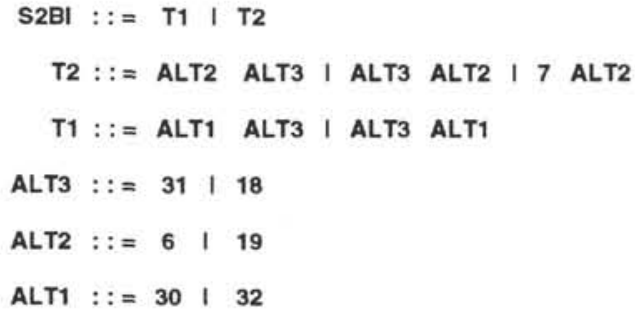

Parsed Sequence:

(Base) S2B1 S2B1 S2B1 S2B1 S2B1 S2B1 ALT3 7 S2B1 ALT3 S2B1 S2B1 S2B1 S2B1 S2B1 S2B1 S2B1 S2B1 S2B1 S2B1 S2B1 S2B1 S2B1 S2B1 S2B1 S2B1 ALT2 8 S2B1 S2B1 ALT2 7 8 S2B1 (Top)

Figure 12 (continued). 